\title{
Telomerase Gene Therapy: A remission towards Cancer
}

\author{
Sameer Quazi, \\ GenLab Biosolutions Private Limited, Bangalore, Karnataka, India. 560043 \\ Colonel.quazi@gmail.com
}

\begin{abstract}
Telomerase is an enzyme which is culpable for the aliment and stability of telomeres. It also maintains the genomic integrity and chromosomal stability. The progressive shortening of telomeres may cause chromosomal instability and alternation in the telomerase. It may cause telomere attrition which can lead to oncogenic incidence in human. Cancer is a disease which is induced by genetic alternations in genes. The genetic mutation within the hTERT is a common type of scenario which is generally found above 90 percent of cancer. In cancer, the length of telomere and the activity of telomerase are very important for cancer cells to proliferate and also for the survival of tumors. Cancer cells regulate through several pathways to increase telomerase activity. There have been several advancements developed to inhibit the telomerase activity in cancer cell but the repercussion of those has demonstrated many adverse effects. Research on AAVs mediated telomerase gene therapy has demonstrated prominent outcomes in animal trials. Thus, it has the potential to bring significance shine in the telomerase cancer therapeutics. Here, in this review article we have analyzed studies related to telomerase gene therapeutics to cure cancer. We also have summarized the telomerase function and mechanism of action to cause cancer. Moreover, other current development in the clinical advances of telomerase inhibition in cancer is described.
\end{abstract}

Keywords: Cancer, Telomerase, hTERT, Telomere, Therapeutics, Genomic Integrity.

\section{Highlights}

1. Telomerase attrition has the potential to cause cancer

2. hTERT promoter mutation may cause cancerous incidence in humans.

3. hTERT can be considered as a principal target for telomerase gene therapy.

4. Telomerase gene therapy through AAVs is considered as the most significant cancer therapeutics.

5. Telomerase shortening may cause age-related diseases alongside cancer. 


\section{Introduction}

Cancer is specified as a group of diseases which includes aberrant growth of cells. It has significance to metastasize or spread to the whole body from a specific site. Cancer is generally caused by genetic alternation or mutation of genes which makes it very complex to cure. It is a hereditary disease that develops as people age. Whenever healthy cells amass genomic instability over time and develop the ability to replicate immortally, cancer occurs. Telomere attrition causes chromosomal instability and it also induce genomic rearrangements in cells which might lead to cancer during consecutive cell divisions. Telomere attrition follows several steps in the proliferation of cells which develops DNA damage responses at the end of the chromosome. Along with cancer, numerous age-related diseases occur due to DNA damage by telomere attrition. Moreover, organ failure, stem cell depletion, progressive tissue degeneration and dysfunctional tissue repair are induced by telomere loss and up capping of chromosomes [1]. Throughout the years, several advancements are being developed to overcome telomere attrition to revitalize and restore aged cells' regenerative abilities.

Telomere illustrates an essential role in the preservation of genomic information on DNA. It has the particular DNA protein structures which is generally found at the end of chromosomes. It has the capability to save the genome from nucleolytic disruption, unwanted recombination, repair and interchromosomal fusion. In every cell division, there is a loss of a small amount of telomeric DNA, which is a normal biological process occurs in every living species. If the telomere length reaches to a crucial limit, the cell goes through apoptosis or senescence. The length of telomere might therefore be used as a biological clock to calculate an organism's lifetime.

In eukaryotic cell, telomeres are ended with a single stranded overhang of three prime which is enclosed by shelterin. With the association of three core subunits, the shelterin complex is made. The subunits are TRF1, TRF2, and POT1. The shelterin complex is important for telomere stability maintenance because it allows the response machinery of DNA damage to differentiate telomeres from the portion of genomic DNA damage. Shelterin is required for capping, and it also protects liner chromosomal from breaking also known as double strand breaks [2-5] (Figure 1). A specialized protein known as telomerase has been created to repair broken telomeres in some particular cells. It is a naturally occurring RNA-containing enzyme that can generate repeated sequences which aids embryonic stem cells to preserve genomic integrity. Telomerase is the enzyme that adds telomere repeats to the ends of chromosomes to lengthen telomeres [6,7].

Despite the potential advantages of TL gene therapy, the activation of telomerase has been associated with oncogenesis, since cancer cells commonly reactivate and upregulate telomerase activity in order to attain immortality $[4,5]$. Oncogenic telomerase mutations escape senescence, allowing cancer cells to proliferate indefinitely and rapidly for disease development. To treat incurable disease such as cancer, telomerase gene therapy needs gene silencing rather than gene transfer or activation, as in regenerative or anti-aging applications. Because various therapeutic aims necessitate distinct polarities of telomerase gene control, double-edged telomerase gene therapy should be safely managed to determine the therapeutic advantages and dangers. The purpose of this study is to describe how various telomerase gene therapy techniques are being studied to treat cancer.

\section{Telomerase and its association with cancer}

Telomerase is a naturally occurring RNA-containing enzyme that is capable of synthesizing repeating telomere sequences [6], which aids in the maintenance of the genome's integrity. Telomerase is essential for protruding telomeres by incorporating telomere repeats into chromosomal ends [7]. It is a complex of ribonucleoproteins [8]. Telomerase reverse transcriptase and telomerase RNA with a template site for DNA elongation are the key enzymes. Additionally, the telomerase complex comprises a number of auxiliary components that enable telomerase to operate in vivo. Some of these 
components are necessary for telomerase to bind to the telomere during a certain cell cycle phase [9], whereas others are required for telomerase activity regulation [10]. Certain proteins are required for the maturation and degradation of the telomerase complex's components [11]. The quantity of telomerase in various cell types is tightly regulated $[12,13]$. This is critical because telomere shortening and eventually senescence in human cells inhibit cell division's potential [14].

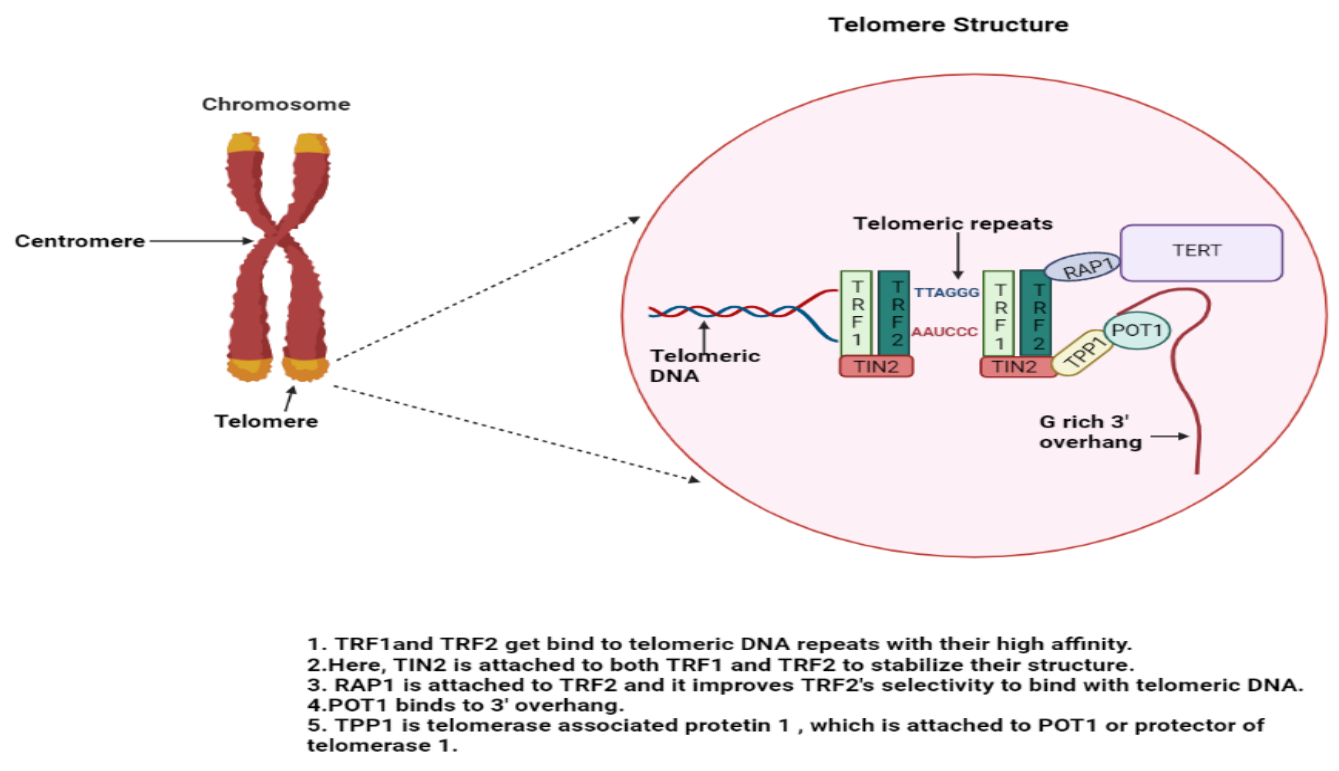

Figure 1: An illustration of the structure of Telomere with three core subunits such as telomeric repeat binding factor 1 and 2 and POT1

Proliferative immorality of cancer cells is achieved by the upregulation of normal silent human TERT gene which codes for the telomerase enzyme with reverse transcriptase activity. A ribonucleoprotein enzyme complex is made by the reverse transcriptase activity of telomerase complex fusion-ed with a functional RNA and many other proteins coded by human telomerase reverse transcriptase complex.

Alternative lengthening of telomeres (ALT) is a DNA recombination process that sometimes reverses telomere attrition to avoid senescence. Generally, in all somatic cell hTERT is normally repressed whereas it is seen to be expressed in $90 \%$ of human malignancies. The underlying processes of hTERT upregulation are still being explored; however, this mostly comprise of hTERT promoter mutation, changes in hTERT amplification, alternative splicing of hTERT pre-mRNA, epigenetic modifications, telomere position effect (TPE) machinery disruption [15].

In cancer cells, there are two specific hTERT promoter mutations are seen, which are known as cytosine to thymidine transition. [16,17]. The alterations are at -124 or 146 base pairs (bp) upstream of the TERT translation start site $[18,19]$ and they are linked to enhanced telomerase activity [20]. As a result, the molecular process that control hTERT regulation and telomerase arrangements have been extensively studied. Robust hTERT suppression may guide to gradual telomere loss and ultimately cancer cell death, according to studies employing telomerase inhibition methods. 


\section{hTERT Mutation}

Human telomere reverse transcriptase gene is 40 kilo base pair, and it contains 15 introns and 16 exons. The human chromosome number 5 (5p15.33) contains hTERT in a nuclease resistant chromatin domain, and it is about 1.2 MBs distant from the telomere [21]. Expression of hTERT is dependent on many factors. hTERT promotor is enriched with GC content and insufficient in TATA and CAAT sequence. TAAT encodes proteins for both eukaryotes and prokaryotes and it is generally found in the promoter region of gene whereas CAAT only found in the eukaryote's promoter region, and it includes binding sites of many factors for transcription.

The hTERT promoter core is a 260-bp proximal region which is accountable for the majority of transcriptional activity. It has five GC boxes (GGGCGG), that are indispensable for hTERT promoter activity and serve as binding sites for the zinc finger transcription factor SP1. Several enhancers binding proteins, including MYC/MAX/MXD1 family and USF1/2, bind to 2 e- boxes (5'-CACGTG$3^{\prime}$ ) found at -165 and +44 of the nucleotide sequences of hTERT relative to the transcription start site. The E-boxes are required for c-MYC activation of the hTERT promoter. They are attached to MAD1 and USF1 to regulate hTERT repression. A single TSS in the hTERT promoter core binds the multifunctional transcription factor TFII-I. Multiple transcription factors and the telomere chromatin environment influence the transcription of the hTERT promoter (Figure 2). Nevertheless, it is still unknown how transcription factors interact with the telomere chromatin environment to regulate hTERT transcription. For the activation or repression of hTERT transcription, many transcription factors bind to the core of the hTERT promoter. Transcription factors such E-twenty-six (ETS) family members, c-MYC, SP1, NF-kB, AP-2, and HIF-1 upregulate the transcription process.
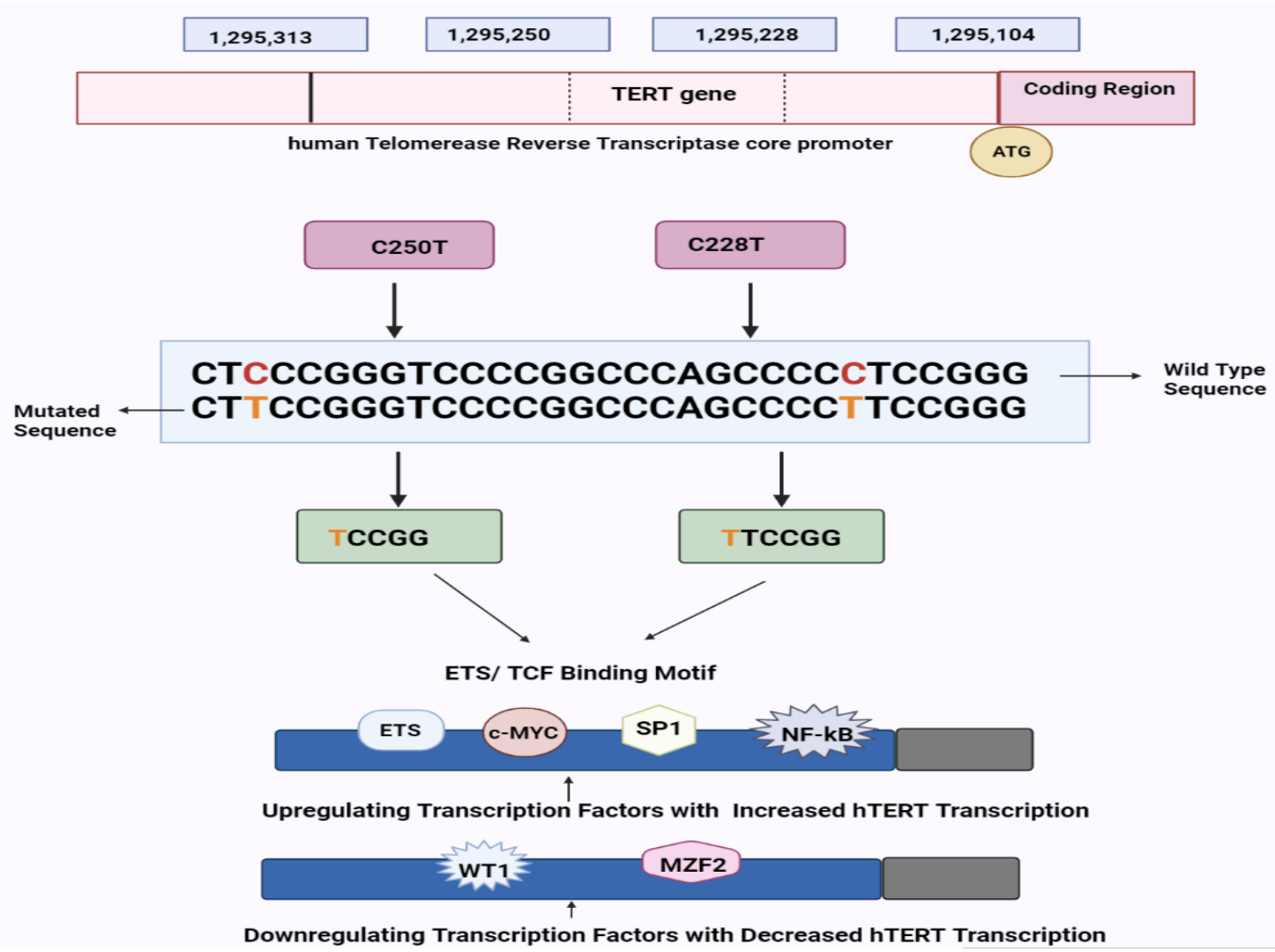

Figure 2: hTERT promoter mutation in telomeric DNA 
Transcription factors were found to downregulate the transcription process of hTERT transcription. p53 (also known as TP53; represses transcription in an SP1-dependent way), WT1, MZF-2, SIP1, MAD (transcription factor implicated in a network regulating cell cycle progression), and Menin are some known transcription factors. Most of these factors that upregulate the telomerase gene are broadly expressed; thus, they cannot completely explain for the high levels of hTERT expression and activity seen during cancer.

\section{Human Telomerase Reverse Transcriptase mutation in Cancer}

Two very recurrent mutations in the central promoter region of hTERT have recently been discovered, suggesting one potential pathway for telomerase activation in cancer cells. The mutation in TERT promoter generally happens at two different region of chromosome 5 at $-124 \mathrm{bp}$ and $-146 \mathrm{bp}$ from ATG start point along with a transition of cytidine to thymidine which are known as C228T and C250T. Following the mutations, two twin nucleotides stretch of $11 \mathrm{bp}$ are produced. ETS transcription factor acts as a transcriptional repressor, activator or regulator to regulate expression of telomerase $[16,17]$.

The biological pathway of ETS is still little known to us but studies have shown that ETS 2 can bind with hTERT promoter in lung carcinoma when EGF mediates the telomerase activation in it [22]. A germline mutation was first reported as a hTERT mutation from a melanoma inherited family. Later it was confirmed through whole genome sequencing of sporadic melanoma (in $>74 \%$ melanomas) and a number of cell lines across several cancer types which were associated with increased hTERT promoter activity $[16,17]$. hTERT mutations occur in approximately $60 \%$ of hepatocellular carcinomas, $60 \%$ of bladder cancers, $50 \%$ of cutaneous squamous cell carcinomas, up to $30 \%$ of thyroid cancers, $70 \%$ of melanomas, $80-90 \%$ of glioblastomas, $70 \%$ of basal cell carcinomas, and approximately $72 \%$ of oligodendrogliomas [17,19, 22-25]. Furthermore, hTERT mutation of chromosome 5 at $-57 \mathrm{bp}$ from ATG start point along with adenine to thymidine transition is found in various cancer types on the following position of chromosome 5: 1,295,248-1,295,243 CC>TT; $1,295,228 \mathrm{C}>\mathrm{A}$; and 1,295,161 A>C [26].

C228T mutations are more common than C250T mutations in a variety of cancers, and their presence is mutually exclusive, implying functional redundancy. Indeed, primary tumors with mutation exhibit much greater amounts of TERT mRNA and telomerase activity, indicating that TERT expression is stimulated $[26,27]$.

Chiba et al. discovered that when human pluripotent stem cells were transduced with a C228T mutation in the TERT promoter region, these cells constitutively expressed TERT and telomerase, in marked contradiction to the TERT promoter which was wild type. They were carrying stem cellderived progenies, in which TERT transcription was halted following cellular differentiation [28]. Additionally, differentiated cells expressing the altered TERT promoter had longer telomeres and lacked the replicative senescence caused by telomere attrition seen in normal cells [28].

Furthermore, research performed Li et al. and his companions has changed the TERT promoter in normal human bladder stem cells by inserting C228T mutation and found that this single event was sufficient to induce transformation [29]. Thus, their results establish unequivocally that the presence of each mutation imparts immortality or the capacity for prolonged proliferation on cells and promotes their transformation through telomerase activation.

A study by Huang et al. [17] constructed TERT promoter and reporter by inserting C228T and C250T mutation. In the study they have found a significant increase in promoter activity, indicating a gain-offunction impact on TERT transcription. The mutations resulted in the formation of ETS transcription factor's de novo binding sites. [17,30]. 
Additionally, two research has demonstrated that GA-binding proteins (GABPA and GABPB1), members of the ETS family transcription factors, were attracted preferentially to the mutant TERT promoter than wild type in cancer cells, stimulating TERT transcription and telomerase [30,31]. Inhibiting GABPA or GABPB1 expression, but not other ETS members, consistently resulted in decreased expression of TERT in tumor cells harboring a mutant TERT promoter [30,31].

In cancer cells with heterozygous TERT promoter mutations, the mutant promoter binds GABPA and has the active chromatin mark $\mathrm{H} 3 \mathrm{~K} 4 \mathrm{me} 2 / 3$ [32].

According to these findings, only the mutant promoters are transcriptionally active. Additionally, GABPA must build a heterotetrametric complex [(GABPA/GABPB)2] with the help of GABPB1 or GABPB2 in order to bind DNA and regulate transcription. Mancini et al. demonstrated that GABPB1depleted glioblastoma cells harboring a mutant TERT promoter displayed comparable reduced TERT expression, as well as poorer proliferation/survival, telomere shortening/dysfunction, and lower tumorigenic potential [31]. In light of these results, as well as previously reported oncogenic effects on leukemia, prostrate and breast [33], GABPA/B1 has been proposed as a new therapeutic target for cancers harboring a mutant TERT promoter [32].

Interestingly, the findings from research by $\mathrm{X}$ et al., has shown thyroid cancer (TC) trials cast doubt on its efficacy as a therapeutic target [34]. To begin, GABPA depletion significantly reduces the expression of TERT in the derived cells of thyroid cancer, regardless of TERT promoter mutations; Secondly, in the primary tumors of thyroid cancer patient's GABPA expression is negatively correlated with TERT expression; and Third, GABPA depletion significantly elevated TC cell invasion despite decreased TERT expression. Ironically, they identified DICER1 as a direct target gene for GABPA. DICER1 is a component of the microRNA machinery that inhibits cancer metastasis. GABPA suppresses the invasive behavior of thyroid cancer cells by increasing DICER1 expression. Fourth, in TC patients, GABPA expression is related with aggressive disease and poor outcomes. Finally, inhibiting GABPB1 regulation in thyroid cancer cells increased invasive-ness while decreasing TERT expression (Unpublished data). Moreover, to C228T and C250T mutations, a subgroup of cancers had CC > TT tandem mutations at positions -124/125 bp and -138/139 (from ATG) $[26,35]$. Additionally, these two tandem mutations provide the ETS transcription factor-binding motif [26]. Currently, a variation at the MYC binding domain in the TERT promoter was identified in eight percent of clear cell renal cell carcinoma (ccRCC) tumors [35]. It is proposed that this type of alternation prevents repressors from the MYC network family from binding, thus de-repressing TERT transcription [35]. These tumors had the longest telomeres in comparison to the wild-type and C228T/C250T-TERT promoters [35].

The precise functional implications of this genetic variation are unknown, and they are also uncertain whether this mutation is specific to ccRCC or is seen in other malignancies, necessitating further research. The rate of TERT promoter mutations varies considerably across investigated human malignancies, ranging from undetectable to more than $90 \%$, and it is still unclear what causes such disparate mutation distributions among various kinds of cancer [26]. The researchers have discovered a negative correlation among the presence of TERT promoter mutations and telomere length in malignancies [26, 36]. Additionally, older age is strongly linked with the incidence of mutations; since increasing telomere loss occurs with age, the mutation connection is most likely attributable to shorter telomeres. Telomere dysfunction is well known as a cause of genomic instability [37], and shorter telomeres can be considered as a prime factor in the initiation of the TERT promoter mutation during malignant transformation. A new study from Garcia's group substantially supports this perspective.

They found that spontaneous mutations in the TERT promoter were chosen from non-tumor people with very short telomeres owing to germline abnormalities in the TERT protein or other telomerase substances [38]. It was discovered that germline variations at the TERT locus had a substantial effect 
on the frequency of TERT promoter mutations in patients with HCC, and that the TERT rs2736100$\mathrm{CC}$ cancer risk genotype was more often observed in individuals with a wild-type TERT promoter [39]. This variation has been shown to increase TERT expression, reversing telomere shortening [40].

Although, non-coding hTERT promoter mutations are the common in cancer, the amount and frequency of these mutations vary by cancer type. TERT promoter mutations are found in the highest frequency in melanoma, pleomorphic dermal sarcoma, myxoid liposarcoma, glioma, urothelial cell carcinoma, carcinoma of the skin, and liver cancer, while in gastric cancer, pancreatic cancer, nonsmall-cell lung cancer, and gastrointestinal stromal tumors it has low frequency $[41,42,43]$. Incipient cancer cells derived from fast self-renewing telomerase-competent cells do not need TERT promoter mutations to maintain TL.

As a result, malignancies originating from these quickly proliferate cells that have fewer hTERT promoter mutations and are more likely to permanently upregulate enzyme activity which is normally reversibly controlled. To circumvent the short-telomere-dependent proliferative barrier, malignancyinducing factors arising from cells with poor self-renewal capacity may need TERT promoter alterations. Prostate cancer is considered as a malignancy with low cell self-renewing capability. The TERT promoter mutations have not observed in this cancer which clearly indicates that the alternation in the core promoter of TERT gene do not play any role in the carcinogenesis process.[44].

Most malignancies contain hTERT promoter variation, which has been found in all level and grades of cancers which indicates that the hTERT mutations are a frequent early event in the carcinogenesis $[45,46]$.

It would be fascinating to observe whether these mutations mostly occur during the time when cells are under crisis, in order to assess if these mutations have a role in the malignant transformation process. According to The Cancer Genome Atlas, there has been twenty-eight projects enrolled with 292 TERT promoter mutation across variety of cancer. The following data has been extracted from the TCGA website to have a clear view on the information (Table 1 and Figure 3) 


\begin{tabular}{|c|c|c|c|c|c|}
\hline Project Number & Project Name & Disease Type & Primary Infection Site & Case Number & Percentage \\
\hline$\underline{\text { CMI-ASC }}$ & $\begin{array}{l}\text { The Angiosarcoma } \\
\text { (ASC) Project }\end{array}$ & $\begin{array}{l}\text { - Soft Tissue Tumors and } \\
\text { Sarcomas, NOS }\end{array}$ & $\begin{array}{ll}\text { - } & \text { Bladder } \\
\text { - } & \text { Breast } \\
\text { - } & \text { Bronchus and lung } \\
\text { - } & \text { Lymph nodiastinum, and pleura } \\
\text { - } & \text { Other and ill-defined digestive organs } \\
\text { - Other and ill-defined sites } \\
\quad \text { Other and ill-defined sites within respiratory system } \\
\text { - } \quad \text { Skind intrathoracic organs }\end{array}$ & 36 & $13.89 \%$ \\
\hline TCGA-UCEC & $\begin{array}{l}\text { Uterine Corpus } \\
\text { Endometrial Carcinoma }\end{array}$ & $\begin{array}{ll}\text { - } & \text { Adenomas and } \\
& \text { Adenocarcinomas } \\
\text { - } & \text { Cystic, Mucinous and } \\
& \text { Serous Neoplasms } \\
\text { - } & \text { Epithelial Neoplasms, NOS } \\
\text { - } & \text { Not Reported }\end{array}$ & $\begin{array}{l}\text { - } \quad \text { Corpus uteri } \\
\text { - } \quad \text { Uterus, NOS }\end{array}$ & 530 & $6.98 \%$ \\
\hline$\underline{\text { TCGA-SKCM }}$ & $\begin{array}{l}\text { Skin Cutaneous } \\
\text { Melanoma }\end{array}$ & - Nevi and Melanomas & - Skin & 469 & 6.61 \\
\hline CPTAC-3 & $\begin{array}{l}\text { CPTAC-Brain, Head } \\
\text { and Neck, Kidney, } \\
\text { Lung, Pancreas, Uterus }\end{array}$ & $\begin{array}{ll}\text { - } & \text { Adenomas and } \\
& \text { Adenocarcinomas } \\
\text { - } & \text { Ductal and Lobular } \\
& \text { Neoplasms } \\
\text { - } & \text { Gliomas } \\
\text { - } & \text { Not Applicable } \\
\text { - } & \text { Squamous Cell Neoplasms }\end{array}$ & $\begin{array}{ll}\text { - } & \text { Brain } \\
\text { - } & \text { Bronchus and lung } \\
\text { - } & \text { Other and ill-defined sites } \\
\text { - } & \text { Pancreas } \\
\text { - Uterus, NOS }\end{array}$ & 778 & $5.01 \%$ \\
\hline CPTAC-2 & $\begin{array}{l}\text { CPTAC-Breast, Colon, } \\
\text { Ovary }\end{array}$ & $\begin{array}{ll}\text { - } & \text { Adenomas and } \\
& \text { Adenocarcinomas } \\
\text { - } & \text { Cystic, Mucinous and } \\
& \text { Serous Neoplasms } \\
\text { - } & \text { Ductal and Lobular } \\
& \text { Neoplasms } \\
\text { - } & \text { Not Reported } \\
\text { - } & \text { Squamous Cell Neoplasms }\end{array}$ & $\begin{array}{l}\text { - } \text { Breast } \\
\text { - } \text { Oton } \\
\text { - Over and unspecified female genital organs } \\
\text { - Rectum } \\
\text { - Retroperitoneum and peritoneum }\end{array}$ & 328 & $4.57 \%$ \\
\hline
\end{tabular}




\begin{tabular}{|c|c|c|c|c|c|}
\hline$\underline{\mathrm{HCMI}-\mathrm{CMDC}}$ & $\begin{array}{l}\text { NCI Cancer Model } \\
\text { Development for the } \\
\text { Human Cancer Model } \\
\text { Initiative }\end{array}$ & $\begin{array}{ll}\text { - } & \text { Adenomas and } \\
& \text { Adenocarcinomas } \\
\text { - } & \text { Complex Epithelial } \\
& \text { Neoplasms } \\
\text { - } & \text { Complex Mixed and } \\
& \text { Stromal Neoplasms } \\
\text { - } & \text { Cystic, Mucinous and } \\
& \text { Serous Neoplasms } \\
\text { - } & \text { Ductal and Lobular } \\
\text { - Neoplasms } \\
\text { - } \quad \text { Gpithelial Neoplasms, NOS } \\
\text { - } \text { Miscellaneous Bone Tumors } \\
\text { - } & \text { Myomatous Neoplasms } \\
\text { - } & \text { Nevi and Melanomas } \\
\text { - Soft Tissue Tumors and } \\
& \text { Sarcomas, NOS }\end{array}$ & $\begin{array}{l}\text { - } \text { Bones, joints and articular cartilage of other and } \\
\text { - } \text { Unspecified sites } \\
\text { - Breast } \\
\text { - } \text { Bronchus and lung } \\
\text { - Colon } \\
\text { - } \text { Esophective, subcutaneous and other soft tissues } \\
\text { - Kidney } \\
\text { - Other and intrahepatic bile ducts } \\
\text { - Rancreas } \\
\text { - Rectosigmoid junction } \\
\text { - Skin } \\
\text { - Small intestine } \\
\text { Stomach }\end{array}$ & 109 & $3.67 \%$ \\
\hline TCGA-STAD & $\begin{array}{l}\text { Stomach } \\
\text { Adenocarcinoma }\end{array}$ & $\begin{array}{ll}\text { - } & \text { Adenomas and } \\
& \text { Adenocarcinomas } \\
\text { - } & \text { Cystic, Mucinous and } \\
& \text { Serous Neoplasms }\end{array}$ & - Stomach & 440 & $3.41 \%$ \\
\hline$\underline{\text { TCGA-GBM }}$ & $\begin{array}{l}\text { Glioblastoma } \\
\text { Multiforme }\end{array}$ & $\begin{array}{ll}\text { - } & \text { Gliomas } \\
\text { - } & \text { Not Reported }\end{array}$ & - Brain & 393 & $2.80 \%$ \\
\hline$\underline{\text { TCGA-CESC }}$ & $\begin{array}{l}\text { Cervical Squamous Cell } \\
\text { Carcinoma and } \\
\text { Endocervical } \\
\text { Adenocarcinoma }\end{array}$ & $\begin{array}{ll}\text { - } & \text { Adenomas and } \\
& \text { Adenocarcinomas } \\
\text { - } & \text { Complex Epithelial } \\
& \text { Neoplasms } \\
\text { - } & \text { Cystic, Mucinous and } \\
& \text { Serous Neoplasms } \\
\text { - } & \text { Squamous Cell Neoplasms }\end{array}$ & - Cervix uteri & 289 & $2.77 \%$ \\
\hline
\end{tabular}




\begin{tabular}{|c|c|c|c|c|c|}
\hline$\underline{\text { TCGA-MESO }}$ & Mesothelioma & - Mesothelial Neoplasms & $\begin{array}{l}\text { - } \quad \text { Bronchus and Lung } \\
\text { - Heart, mediastinum and pleura }\end{array}$ & 82 & $2.44 \%$ \\
\hline$\underline{\text { TCGA-LUSC }}$ & $\begin{array}{l}\text { Lung Squamous Cell } \\
\text { Carcinoma }\end{array}$ & - Squamous Cell Neoplasms & - Bronchus and lung & $\underline{495}$ & $2.22 \%$ \\
\hline$\underline{\text { TCGA-LIHC }}$ & $\begin{array}{l}\text { Liver Hepatocellular } \\
\text { Carcinoma }\end{array}$ & $\begin{array}{ll}\text { - } & \text { Adenomas and } \\
& \text { Adenocarcinomas } \\
\end{array}$ & - Liver and intrahepatic bile ducts & $\underline{364}$ & $2.20 \%$ \\
\hline TCGA-PAAD & $\begin{array}{l}\text { Pancreatic } \\
\text { Adenocarcinoma }\end{array}$ & $\begin{array}{ll}\text { - } & \text { Adenomas and } \\
& \text { Adenocarcinomas } \\
\text { - } & \text { Cystic, Mucinous and } \\
\text { Serous Neoplasms } \\
\text { - } & \text { Ductal and Lobular } \\
\text { Neoplasms } \\
\text { - } & \text { Epithelial Neoplasms,NOS }\end{array}$ & - Pancreas & $\underline{182}$ & $2.20 \%$ \\
\hline$\underline{\text { TCGA-KIRP }}$ & $\begin{array}{l}\text { Kidney Renal Papillary } \\
\text { Cell Carcinoma }\end{array}$ & $\begin{array}{ll}\text { - } & \text { Adenomas and } \\
& \text { Adenocarcinomas } \\
\end{array}$ & - Kidney & $\underline{281}$ & $1.78 \%$ \\
\hline
\end{tabular}




\begin{tabular}{|c|c|c|c|c|c|}
\hline TCGA-HNSC & $\begin{array}{l}\text { Head and Neck } \\
\text { Squamous Cell } \\
\text { Carcinoma }\end{array}$ & - Squamous Cell Neoplasms & 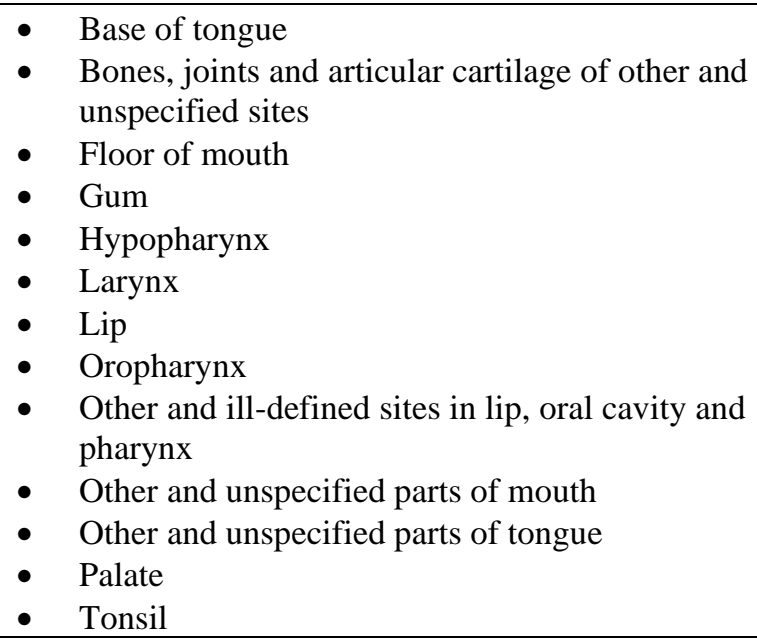 & $\underline{508}$ & $1.77 \%$ \\
\hline TCGA-LUAD & Lung Adenocarcinoma & $\begin{array}{ll} & \text { Acinar Cell Neoplasms } \\
\text { - } & \text { Adenomas and } \\
& \text { Adenocarcinomas } \\
\text { - } & \text { Cystic, Mucinous and } \\
& \text { Serous Neoplasms }\end{array}$ & - Bronchus and lung & $\underline{567}$ & $1.76 \%$ \\
\hline TCGA-COAD & Colon Adenocarcinoma & $\begin{array}{ll}\text { - } & \text { Adenomas and } \\
& \text { Adenocarcinomas } \\
\text { - } & \text { Complex Epithelial } \\
& \text { Neoplasms } \\
\text { - } & \text { Cystic, Mucinous and } \\
& \text { Serous Neoplasms } \\
\text { - } & \text { Epithelial Neoplasms, NOS }\end{array}$ & $\begin{array}{ll}\text { - } & \text { Colon } \\
\text { - } & \text { Rectosigmoid junction }\end{array}$ & 400 & $1.75 \%$ \\
\hline
\end{tabular}




\begin{tabular}{|c|c|c|c|c|c|}
\hline$\underline{\text { TCGA-SARC }}$ & Sarcoma & $\begin{array}{ll}\text { - } & \text { Fibromatous Neoplasms } \\
\text { - } & \text { Lipomatous Neoplasms } \\
\text { - } & \text { Myomatous Neoplasms Sheath Tumors } \\
\text { - } & \text { Soft Tissue Tumors and } \\
& \text { Sarcomas, NOS } \\
\text { - } & \text { Synovial-like Neoplasms }\end{array}$ & 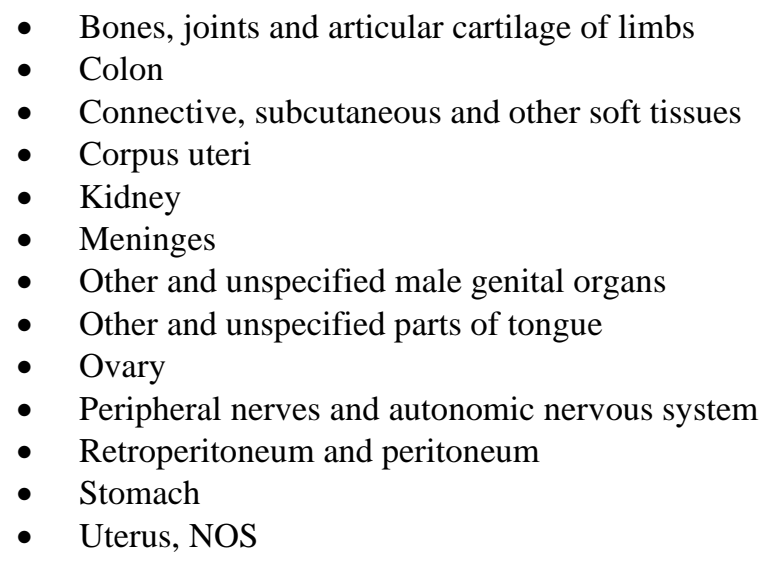 & 237 & $1.69 \%$ \\
\hline$\underline{\text { TCGA-ESCA }}$ & Esophageal Carcinoma & $\begin{array}{ll}\text { - } & \text { Adenomas and } \\
& \text { Adenocarcinomas } \\
\text { - } & \text { Cystic, Mucinous and } \\
& \text { Serous Neoplasms } \\
\text { - } & \text { Squamous Cell Neoplasms }\end{array}$ & $\begin{array}{l}\text { - Esophagus } \\
\text { - Stomach }\end{array}$ & 184 & $1.63 \%$ \\
\hline TCGA-READ & $\begin{array}{l}\text { Rectum } \\
\text { Adenocarcinoma }\end{array}$ & $\begin{array}{ll}\text { - } & \text { Adenomas and } \\
& \text { Adenocarcinomas } \\
\text { - } & \text { Cystic, Mucinous and } \\
& \text { Serous Neoplasms }\end{array}$ & $\begin{array}{l}\text { - } \text { Colon } \\
\text { - } \text { Connective, subcutaneous and other soft tissues } \\
\text { - Rectosigmoid junction } \\
\text { - } \text { Rectum } \\
\text { Unknown }\end{array}$ & 137 & $1.46 \%$ \\
\hline TCGA-BLCA & $\begin{array}{l}\text { Bladder Urothelial } \\
\text { Carcinoma }\end{array}$ & $\begin{array}{ll}\text { - } & \text { Adenomas and } \\
& \text { Adenocarcinomas } \\
\text { - } & \text { Epithelial Neoplasms, NOS } \\
\text { - } & \text { Squamous Cell Neoplasms } \\
\text { - } & \text { Transitional Cell Papilloma } \\
& \text { and Carcinomas }\end{array}$ & - Bladder & 412 & $1.46 \%$ \\
\hline
\end{tabular}

Adenocarcinomas

Cystic, Mucinous an

Serous Neoplasms

Adenomas and

Adenocarcinomas

Cystic, Mucinous an

Adenomas and

Adenocarcinomas

Transitional Cell Papillom
Bones, joints and articular cartilage of limb

Connective, subcutaneous and other soft tissues

Meninges

- Ovary

Connective, subcutaneous and other soft tissue

Bladder

412 


\begin{tabular}{|c|c|c|c|c|c|}
\hline$\underline{\text { TCGA-KIRC }}$ & \begin{tabular}{|l|} 
Kidney Renal Clear Cell \\
Carcinoma
\end{tabular} & $\begin{array}{ll}- & \text { Adenomas and } \\
& \text { Adenocarcinomas } \\
\end{array}$ & - Kidney & 336 & $1.19 \%$ \\
\hline $\begin{array}{l}\text { MMRF- } \\
\text { COMMPASS } \\
\end{array}$ & $\begin{array}{l}\text { Multiple Myeloma } \\
\text { CoMMpass Study }\end{array}$ & - Plasma Cell Tumors & - Hematopoietic and reticuloendothelial systems & 959 & $1.04 \%$ \\
\hline$\underline{\text { TCGA-BRCA }}$ & $\begin{array}{l}\text { Breast Invasive } \\
\text { Carcinoma }\end{array}$ & $\begin{array}{ll}\text { - } & \text { Adenomas and } \\
& \text { Adenocarcinomas } \\
\text { - } & \text { Adnexal and Skin } \\
& \text { Appendage Neoplasms } \\
\text { - } & \text { Basal Cell Neoplasms } \\
\text { - } & \text { Complex Epithelial } \\
& \text { Neoplasms } \\
\text { - } & \text { Cystic, Mucinous and } \\
& \text { Serous Neoplasms } \\
\text { - } & \text { Ductal and Lobular } \\
& \text { Neoplasms } \\
\text { - } & \text { Epithelial Neoplasms, NOS } \\
\text { - } & \text { Fibroepithelial Neoplasms } \\
\text { - } & \text { Squamous Cell Neoplasms }\end{array}$ & - Breast & 986 & $0.81 \%$ \\
\hline TCGA-THCA & Thyroid Carcinoma & $\begin{array}{ll}\text { - } & \text { Adenomas and } \\
& \text { Adenocarcinomas } \\
\text { - } & \text { Epithelial Neoplasms, NOS }\end{array}$ & - Thyroid gland & $\underline{492}$ & $0.61 \%$ \\
\hline$\underline{\text { TCGA-LGG }}$ & $\begin{array}{l}\text { Brain Lower Grade } \\
\text { Glioma }\end{array}$ & - Gliomas & - Brain & 510 & $0.59 \%$ \\
\hline$\underline{\text { TCGA-OV }}$ & $\begin{array}{l}\text { Ovarian Serous } \\
\text { Cystadenocarcinoma }\end{array}$ & $\begin{array}{ll}\text { - } & \text { Cystic, Mucinous and } \\
& \text { Serous Neoplasms } \\
\text { - } & \text { Not Reported }\end{array}$ & - Ovary & 436 & $0.46 \%$ \\
\hline$\underline{\text { TCGA-PRAD }}$ & $\begin{array}{l}\text { Prostate } \\
\text { Adenocarcinoma }\end{array}$ & $\begin{array}{ll}\text { - } & \text { Adenomas and } \\
& \text { Adenocarcinomas } \\
\text { - } & \text { Cystic, Mucinous and } \\
& \text { Serous Neoplasms } \\
\text { - } & \text { Ductal and Lobular } \\
& \text { Neoplasms }\end{array}$ & - Prostate gland & 498 & $0.20 \%$ \\
\hline
\end{tabular}

Table 1: TERT promoter mediated cancer (DATA allocated from the Cancer Genome Atlas) 


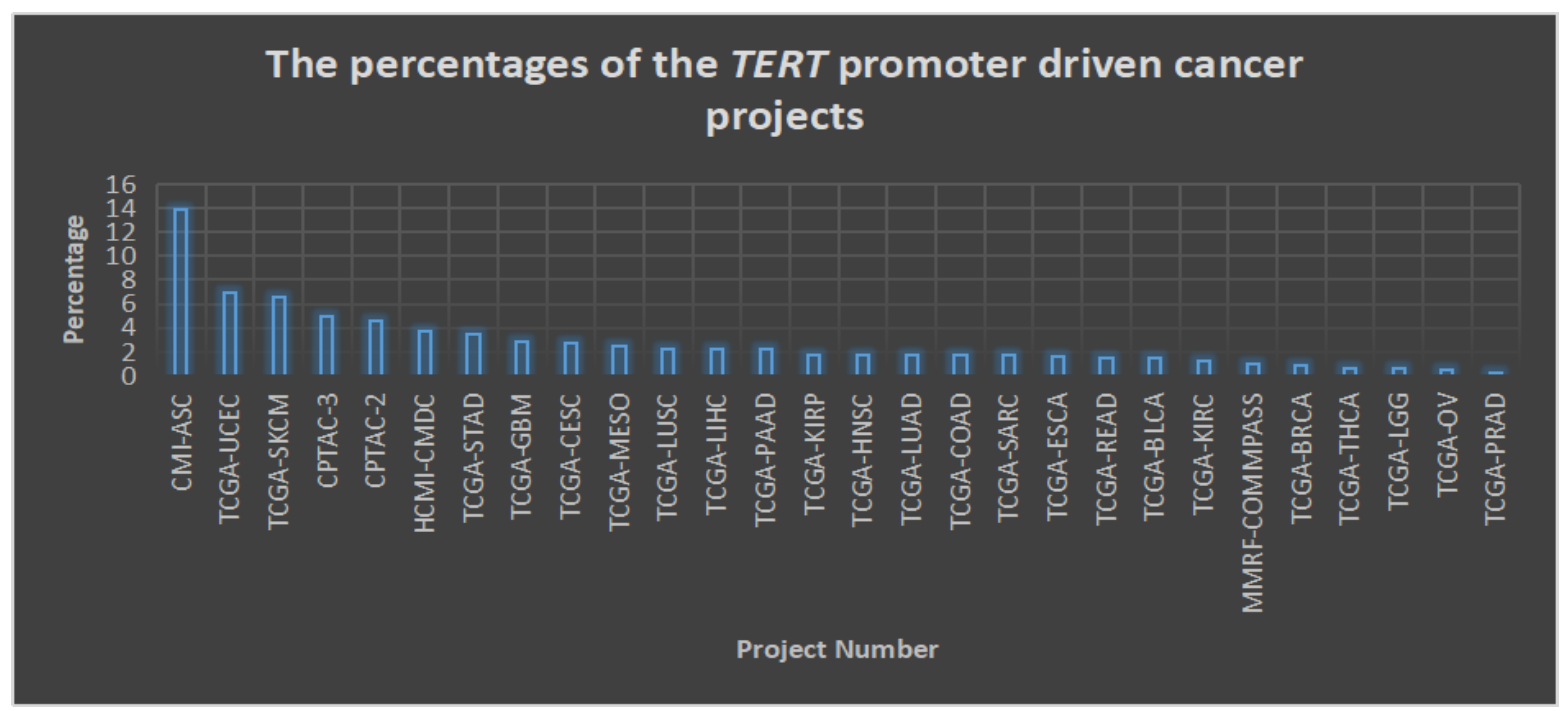

Figure 3: A graphical representation of the frequency of TERT promoter mutation in variety of cancer.

\section{Anti-cancer treatment through Telomerase Gene Therapy: A Case Analysis}

Telomerase gene therapy has been recognized as one of the key targets to develop effective treatment for cancer. Telomerase has expressed its presence in most of the cancers. Furthermore, compared to cancer cells, healthy cells, including stem cells, have reduced telomerase activity and typically retain longer telomeres. These characteristics offer an advantage by reducing the likelihood of telomere shortening in normal cells. The primary goal of anti-telomerase therapy is to cause apoptosis and cell death in cancer cells while limiting side effects in healthy cells [47].

\section{Cancer Therapy through TAGE System}

A new telomerase directed gene therapy has been invented by Dan et al., and his team. They have studied the biological mechanism of CRISPR Cas9 and telomerase and developed the gene therapy named TAGE. Cas9 was used as an effector gene to induce death in cancer cells by TAGE system. Following their research, adeno associated virus can be used as effector gene to treat in vivo tumor [48].

The novel telomerase and CRISPR Cas9 based gene therapy for cancer named TAGE was also known as telomerase activity gene expression. This therapy includes a three prime single stranded sequence 3'-TT GGGATT GGGATT-5' which is transferred into cancer cell. The mechanism of action will be elongated by telomerase, and it will make a synthesized double stranded telomere repeat sequence at the end of effector. The nuclease dead Cas9 -VP64 and a telomeric DNA targeting sgRNA (TsgRNA) will be released by adeno-associated vector into cancer cell. The combination of this will create a complex named dCas9-VP69-TsgRNA which is an artificial transcription factor. It has the capability to get attached with the synthesized telomeric DNA at the end site of effector. Cas9 expression will be activated as the effector gene then. A new complex of Cas9-TsgRNA will be formed by the association of Cas9 protein and TsgRNA. By disrupting the chromosome of cancer cells, this complex will induce apoptosis. Furthermore, TAGE will not harm normal cells as it cannot be activated in normal cells due to absence of telomerase activity. In clinical trial, the TAGE system has successfully induce death to cancer cells such as MDA-MB-453, Hepa1-6, A549, PANC-1, HT-29, HepG2, HeLa, 
SKOV-3, and RAW264.7 by using Cas9 as effector gene. The gene therapy did not cause harm to any normal cells including MRC-5, HL7702 and BMSC.

To perform the clinical trials, the researchers has packed three plasmid TsgRNA-dCas9-VP64, C1$\mathrm{HO}$ and T-HO site-TMCP into adeno-associated virus. The recombinant adeno-associated virus was then testified by the scientists which was combination of three viruses through co-transfecting cells with (rAAVHO, rAAV-TsgRNA-dCas9-VP64, and rAAV-HO site TMCP). The result of this trials illustrated that rAAV-TSD has significantly lessen the HepG2 and Hepa1-6 cancer cells by killing them though there was no harm on normal cells MRC-5 and HL7702 [48].

Such successful outcome in vitro experiment has let the researchers to conduct animal trials with the testified recombinant adeno associated virus TSD. The first animal trial includes mice injected with cancer cell Hepa 1-6 mixed with rAAVs. Following after two weeks, the mice which were transplanted with cancer cells combine with rAAV-MCS, developed tumors with hyperemia on both side of the body. The developed tumor size was 83 and $85 \mathrm{~mm} 3$. The mice were treated with rAAV TSD and it showed significant changes in the tumor quantity and sizes $14 \mathrm{~mm} 3$ and $13 \mathrm{~mm} 3$, respectively.

The malignant cells bearing mice were treated with intravenously administered rAAVs in the second animal trial. As a consequence, mice treated with rAAV-MCS developed significant tumors on both sides, with mean tumor sizes of $237 \mathrm{~mm} 3$ and $293 \mathrm{~mm} 3$ on the left and right sides, respectively. The mice treated with rAAV-TSD, on the other hand, had significantly smaller tumors on both sides, with mean tumor sizes of $12 \mathrm{~mm} 3$ and $20 \mathrm{~mm} 3$ on the left and right sides, respectively.

The maximum number of tumors were eliminated in animal trials which were treated with rAAVTSD. Significantly, no mice died after receiving rAAVs in the two animal trials, suggesting that rAAVs are safe. Finally, in the second animal experiment, they found Cas9 mRNA and viral DNA in different tissues of mice to further investigate the cancer cell-specific expression of the Tage system's effector gene. The virus was found in all identified organs in varying degrees of abundance; however, Cas9 mRNA was seen in tumors of mice that had been injected with rAAV-TSD. The findings suggested that the Tage system could only be activated in cancer cells, resulting in cancer cell-specific effector gene expression.

\section{Telomerase Mediated Suicide Gene Therapy}

A telomerase mediated suicide gene therapy was developed by a group of scientists guided by Kieth et al., where they have found hTR and hTERT as a potential target to create gene therapy to treat cancer as they are actively expressed in numerous cancer cells. To mimic the delivery of telomerasespecific suicide gene therapy vectors, they created a family of adenovirus gene therapy vectors that drive the bacterial nitroreductase gene utilizing transcriptional regulatory regions from the telomerase hTERT and hTR genes (NTR). The NTR gene converts the prodrug CB1954 into an active cytotoxic alkylating agent via bioactivation [49].

They show that NTR is expressed selectively in cancer cells and that transcription of NTR constructs was properly started from both promoters using infection of human cancer and normal cells and Western blotting. These findings suggested that the telomerase promoters' cell-specific activity was preserved in the viral context. Furthermore, in vitro and in vivo, a variety of human cancer cells were sensitized to CB1954 in a promoter-dependent and dose-dependent way, demonstrating distinct hTRNTR and hTERT-NTR mediated increase of CB1954 induced cytotoxicity in monolayers and xenografts. 
Drug resistant derivatives of the A2780 ovarian adenocarcinoma cell line, which are known to tolerate the effects of a variety of DNA damaging drugs such as the alkylating agent $\mathrm{N}$-methyl-N-nitrosourea, the purine analogue 6- thioguanine, and the DNA crosslinker cisplatin, were successfully targeted by this approach in monolayer experiments. They include three normal adult human epithelial cell lines and demonstrate that, despite their high permissiveness for adenovirus infection, neither promoter construct increased CB1954 toxicity in these cells or in normal foetal lung fibroblasts. The insensitivity of three normal adult cell strains to telomerase focused treatments is an intriguing and promising discovery, since telomerase targeted therapies should be characterized by preference for cancer cells over normal cells. Combined together, the findings demonstrate that in viral models of gene transfer, the differential promoter activity of the hTR and hTERT promoters between normal and cancer cells are preserved, thus confirming the fundamental concept underpinning a telomerasedirected strategy in gene therapy.

In conclusion, the addition of Ad-hTR-NTR and Ad-hTERT-NTR to a potential telomerase-specific anti-cancer arsenal is a promising prospect, though optimal telomerase-directed gene therapy systems will presumably require targeted delivery systems as well as a thorough understanding of the regulation of hTR and hTERT genes in target tumors.

\section{TERT promotor driven CRISPR Cas9 Mediated Gene Therapy}

To develop gene therapy, CRISPR Cas9 has illustrated revolutionary outcomes in clinical trials, such as in development of novel cellular immunotherapy, CAR T cell therapy to treat multiple myeloma and also it contributed in artificial intelligence to advance genomic medicine and many more [50-52].

In the year of 2017, A study by Kim et al., used CRISPR Cas9 for the first time to target HRAS oncogene in human bladder cancer. Kim et al., utilized hTERT promoter driven GAL4 for selective activation of CRISPR/Cas9 to target the HRAS oncogene in bladder cancer cells [53].

In particular, the human TERT promoter promotes cancer specific GAL4 expression, and then it attaches to binding system to induce a promoter driving Cas9 nuclease production, resulting in preferred Cas 9 upregulation in cancer cells by a genetic cascade. HRAS was silenced in bladder cancer cell lines by its targeting guide RNA, GAL4, and UAS-activated Cas9 nuclease (HRAS-LV) which was expressed by a lentivirus vector. On the contrary, HRAS was not affected in foreskin fibroblasts, demonstrating the inhibition of HRAS by the hTERT promoter driven CRISPR/Cas9 genetic circuit. In comparison to NC-LV-treated groups, specific inhibition of HRAS by HRAS-LV resulted in selective silencing of bladder cancer cell rapid increase, migration, and invasion, as well as increased apoptotic cancer cell death. Thus, it indicates, CRISPR/Cas9-based TERT promoter-driven genetic circuit can be used to selectively inhibit genes which induce carcinogenesis.

\section{Gene Therapeutics by TERT promoter driven Oncolytic Cancer}

Research has created a revised human TERT (mTERT) promoter to drive oncolytic adenovirus replication and evaluated its anticancer effectiveness [54]. In the study the mTERT promoter which contains added Sp1 and c-Myc binding sites induces elevated levels of transgene expression in TERTpositive cancer cells than the unmodified human TERT promoter in which gene expression is 10-fold higher. The result indicates that the promoter activity can be improvise in cancer by inserting additional Sp1 and c-Myc binding sites.

Furthermore, mTERT promoter-driven oncolytic adenovirus replication increased the potential and duration of antitumor effectiveness when compared to control oncolytic adenovirus replication under the control of the unmodified human TERT promoter. 
Prominently, ten days after virus injection, $40 \%$ of mice gained complete tumor regression by the mTERT promoter-driven oncolytic adenovirus. There was no visible tumor for up to two months, which demonstrates that mTERT promoter driven oncolytic adenovirus has more potent and durable tumor growth inhibition than the other human TERT-driven oncolytic adenoviruses.

Moreover, the oncolytic adenovirus replicating under the control of the mTERT promoter had significantly greater cancer selectivity than under the control of the unmodified human TERT promoter. The data suggested that modifying the TERT promoter was required to enhance the oncolytic adenovirus's cancer selectivity and cytolytic activity.

Two distinct modification techniques to enhance mTERT promoters were described in 2018.

The first method combined E2F and mTERT promoters with several copies of hypoxia response elements (HRE) to produce two hypoxia-responsive and cancer-specific promoters (HEmT and HmTE) [55]. In experiment, HEmT illustrates elevated transcriptional activity than HmTE. It demonstrates the order of individual promoter components has a significant impact on hybrid promoter activities. In the both normoxic and hypoxic tumor regions, the active replication of adenovirus has led HEmT promoter-driven oncolytic adenovirus to silence tumor growth more effectively than a clinically approved oncolytic adenovirus (Oncorine) in a highly aggressive orthotopic pancreatic tumor model.

In the second method oncogenic transcription factor binding domains were added [56]. By adding six copies of HRE and five copies of c-Myc binding sites upstream of mTERT (creating H5CmTERT), the mTERT promoter was enhanced further in this study to mediate oncolytic adenovirus replication. Under both normoxic and hypoxic conditions, H5CmTERT promoter-driven oncolytic adenovirus can replicate more efficiently in cancer cells than the mTERT-driven oncolytic adenovirus. It can enhance antitumor efficacy and overcome the commonly observed downregulation of virus replication in the hypoxic tumor region.

\section{Telomerase Gene Therapy through RNA Interference}

To generate telomere dysfunction, one of the methods uses vector-mediated expression of hTERTC27 [57]. A 27-kDa human TERT polypeptide (hTERTC27) is missing many domains required for telomerase activity, including TERC-binding domains of wild-type TERT and conserved reverse transcriptase motifs. Despite RNA interference therapies which straight forwardly inhibit the expression of TERC or TERT to impair telomere maintenance and malignancy, hTERTC27 neither suppresses nor limits telomerase activity [58]. The anticancer activity of hTERC27 in TERT-positive cancer cells is mediated by upregulation of the senescence-associated gene $\mathrm{p} 21$, or by promoting senescence-like growth arrest and apoptosis in cells via nuclear localization of the hTERC27 polypeptide, resulting in chromosome end-to-end fusion [57]. Because direct inhibition of telomerase activity (as in the case of RNA interference) may exert selective pressure on cancer cells to adapt alternative telomere lengthening to maintain telomeres in a telomerase-independent manner $[59,60]$, the indirect effect of hTERTC27 could be beneficial for long-term therapeutic applications. Importantly, lentivirus-mediated persistent expression of hTERC27 in TERT-positive cancer cells reduced tumorigenicity relative to parental cancer cells. In a second study, AAV-mediated expression of hTERTC27 was demonstrated to induce more robust apoptosis, resulting in strong anticancer effects against glioma [61]. These findings demonstrated that vector-mediated expression of hTERTC27 is a feasible cancer treatment approach. 


\section{Anti-telomerase therapeutics besides Gene Therapy}

The development of vaccines has eradicated several types of diseases [62]. Multiple approaches have been made by targeting telomerase to treat cancer through performing cancer cell apoptosis. Antisense oligonucleotides and immune-vaccines are two telomerase targeted therapeutics which has shown significant results in clinical studies in human. Imetelstat has been thoroughly tested in preclinical research due to its activity and effectiveness against a variety of malignant cell lines and in mice xenograft models. It is developed to inhibit telomerase activity by intravenously. It contains a $13 \mathrm{Mer}$ N3'-P5' thio-phosphoramidate oligonucleotide which is connected with a palmitoyl 16 lipid moiety by a $5^{\prime}$-thio-phosphate group. The function of the section of imetestat is listed on the table 2 :

\begin{tabular}{|l|l|}
\hline Section of Imetestat & Function \\
\hline 1. Thio-phosphoramidate & $\begin{array}{l}\text { It is known as the piller of imetestat. It has } \\
\text { the feature like acid. The other excellent } \\
\text { features include metabolic stability, high } \\
\text { aqueous solubility, resistance to the action } \\
\text { of nucleases and also to build RNA } \\
\text { duplexes [63]. }\end{array}$ \\
\hline 2. Lipid moiety & $\begin{array}{l}\text { It increases the cellular uptake in metabolic } \\
\text { process and also it provides retention and } \\
\text { drug efficacy by high lipophilicity [64]. }\end{array}$ \\
\hline
\end{tabular}

Table 2: Structure and Function of Imetestat

A feature which excellence imetestat from other antisense oligonucleotide is, its sequence get attached with a complementary thirteen nucleotide region of human telomerase reverse transcriptase which has high specificity and affinity on the active site of telomerase and direct inhibition of the activity of telomerase.

Imetelstat inhibited telomerase, inducing telomere shortening in cancer cell lines originating from malignancies of the bladder, breast, lung, liver, prostate, and pancreatic [65-67]. The drug was well tolerated and very effective in eliciting telomerase suppression in mice models of human tumor xenografts, guiding towards decreased tumor growth, avoidance of metastasis, and tumor sensitization to conventional treatment [68]. Because of its extremely lipophilic nature, imetelstat was also shown to effectively inhibit tumor development in a xenograft model by crossing the blood-brain barrier in glioblastomas [69]. In a mouse model of Barrett's adenocarcinoma, the combination of nilotinib (tyrosine kinase inhibitor) with imetelstat was shown to be more efficient than either drug alone in suppressing homologous recombination and telomerase activity [70].

Several clinical experiments by using imetestat has been conducted according to registered clinical trials in Clinicaltrials.gov. Among which eleven clinical trials has been completed though few trials have been discontinued or terminated or withdrawn and few are recruiting patients and actively ongoing. The completed clinical trials using imetestat are listed in the following table 3: 


\begin{tabular}{|c|c|c|c|c|c|c|}
\hline $\begin{array}{l}\text { Clinical Trial } \\
\text { identifier no \& } \\
\text { Phase no }\end{array}$ & Type of Cancer & Objective of the study & Drug used & $\begin{array}{l}\text { Participants } \\
\text { Number }\end{array}$ & Start Date & Results \\
\hline $\begin{array}{l}\text { 1.NCT01256762 } \\
\text { Phase: II }\end{array}$ & Metastatic Breast Cancer & Safety and Efficiency & $\begin{array}{l}\text { Imetelstat sodium } \\
\text { Bevacizumab } \\
\text { Paclitaxel }\end{array}$ & 166 & $\begin{array}{l}\text { November } 2010 \text { to } \\
\text { December } 2012\end{array}$ & $\begin{array}{l}\text { No result has been } \\
\text { posted }\end{array}$ \\
\hline $\begin{array}{l}\text { 2.NCT01137968 } \\
\text { Phase: II }\end{array}$ & $\begin{array}{l}\text { Non-small cell Lung } \\
\text { Cancer }\end{array}$ & Safety and Efficiency & $\begin{array}{l}\text { Imetelstat sodium } \\
\text { Bevacizumab }\end{array}$ & 116 & $\begin{array}{l}\text { May } 2010 \text { to } \\
\text { September } 2013\end{array}$ & $\begin{array}{l}\text { No result has been } \\
\text { posted }\end{array}$ \\
\hline $\begin{array}{l}\text { 3.NCT01273090 } \\
\text { Phase: I }\end{array}$ & $\begin{array}{l}\text { Brain and Central } \\
\text { Nervous System Tumors } \\
\text { Lymphoma } \\
\text { Lymphoproliferative } \\
\text { Disorder Small Intestine } \\
\text { Cancer Unspecified } \\
\text { Childhood Solid Tumor, } \\
\text { Protocol Specific }\end{array}$ & $\begin{array}{l}\text { Determination of } \\
\text { MTD, toxicities and } \\
\text { characterize pharma } \\
\text { cytokines. }\end{array}$ & $\begin{array}{l}\text { Imetestat, dose } \\
\text { escalation study }\end{array}$ & 34 & $\begin{array}{l}\text { May } 2011 \text { to } \\
\text { October } 2013\end{array}$ & $\begin{array}{l}\text { No result has been } \\
\text { posted }\end{array}$ \\
\hline $\begin{array}{l}\text { 4.NCT00510445 } \\
\text { Phase: I }\end{array}$ & Lung Cancer & $\begin{array}{l}\text { Safety and the } \\
\text { maximum tolerated } \\
\text { dose (MTD) and dose } \\
\text { limiting toxicity in } \\
\text { combination with } \\
\text { paclitaxel and } \\
\text { carboplatin }\end{array}$ & $\begin{array}{l}\text { Imetelstat Sodium } \\
\text { (GRN163L) }\end{array}$ & 27 & $\begin{array}{l}\text { July } 2007 \text { to April } \\
2011\end{array}$ & $\begin{array}{l}\text { Individuals on imete } \\
\text { lstat who had a short } \\
\text { telomerase had a te } \\
\text { ndency to have a lon } \\
\text { ger median progress } \\
\text { ion free and overall } \\
\text { survival }\end{array}$ \\
\hline
\end{tabular}




\begin{tabular}{|c|c|c|c|c|c|c|}
\hline & & & & & & $\begin{array}{l}\text { Imetelstat This thera } \\
\text { py, on the other han } \\
\text { d, showed no effect } \\
\text { on median progressi } \\
\text { on free and overall s } \\
\text { urvival with long tel } \\
\text { omerase. } \\
\text { ADRs: } \\
\text { thrombocytopenia a } \\
\text { nd neutropenia }\end{array}$ \\
\hline $\begin{array}{l}\text { 5.NCT01731951 } \\
\text { Phase: II }\end{array}$ & $\begin{array}{l}\text { Primary Myelofibrosis } \\
\text { Secondary Myelofibrosis } \\
\text { Myeloid Malignancies }\end{array}$ & Efficacy & Imetestat & 80 & $\begin{array}{l}\text { October } 2012 \text { to } \\
\text { January } 2019\end{array}$ & $\begin{array}{l}\text { Remission in } 21 \% \\
\text { of patients. }\end{array}$ \\
\hline $\begin{array}{l}\text { 6.NCT01265927 } \\
\text { Phase I }\end{array}$ & HER2+ Breast Cancer & $\begin{array}{l}\text { Safety and Biological } \\
\text { effect }\end{array}$ & $\begin{array}{l}\text { GRN163L in } \\
\text { combination with } \\
\text { trastuzumab }\end{array}$ & 10 & $\begin{array}{l}\text { December } 2010 \text { to } \\
\text { October } 2015\end{array}$ & $\begin{array}{l}\text { No result has been } \\
\text { posted }\end{array}$ \\
\hline $\begin{array}{l}\text { 7.NCT00310895 } \\
\text { Phase: I }\end{array}$ & Solid tumor malignancies & $\begin{array}{l}\text { safety and the } \\
\text { maximum tolerated } \\
\text { dose of GRN163L } \\
\text { administration }\end{array}$ & $\begin{array}{l}\text { Imetelstat Sodium } \\
\text { (GRN163L) }\end{array}$ & 85 & $\begin{array}{l}\text { April } 2006 \text { to March } \\
2013\end{array}$ & $\begin{array}{l}\text { DLT: } \\
\text { thrombocytopenia, } \\
\text { myelosuppression. }\end{array}$ \\
\hline $\begin{array}{l}\text { 8.NCT01242930 } \\
\text { Phase: II }\end{array}$ & Multiple myeloma & $\begin{array}{l}\text { To improve the clinical } \\
\text { outcome of patients } \\
\text { who were treated } \\
\text { previously with } \\
\text { imetestat }\end{array}$ & $\begin{array}{l}\text { Drug: Imetelstat }(7.5 \\
\mathrm{mg} / \mathrm{kg}) \\
\text { lenalidomide } \\
\text { standard of care } \\
\text { Imetelstat }(9.4 \\
\mathrm{mg} / \mathrm{kg})\end{array}$ & 13 & $\begin{array}{l}\text { November } 2010 \text { to } \\
\text { December } 2015\end{array}$ & $\begin{array}{l}\text { No result has been } \\
\text { posted. }\end{array}$ \\
\hline
\end{tabular}




\begin{tabular}{|c|c|c|c|c|c|c|}
\hline $\begin{array}{l}\text { 9. NCT00718601 } \\
\text { Phase: I }\end{array}$ & Multiple myeloma & $\begin{array}{l}\text { Safety and the } \\
\text { maximum tolerated } \\
\text { dose (MTD) }\end{array}$ & $\begin{array}{l}\text { Imetelstat Sodium } \\
\text { (GRN163L) }\end{array}$ & 40 & $\begin{array}{l}\text { July } 2008 \text { to October } \\
2011\end{array}$ & $\begin{array}{l}\text { No result has been } \\
\text { posted. }\end{array}$ \\
\hline $\begin{array}{l}\text { 10. NCT00594126 } \\
\text { Phase: I }\end{array}$ & Multiple myeloma & $\begin{array}{l}\text { Safety and the } \\
\text { maximum tolerated } \\
\text { dose (MTD) }\end{array}$ & $\begin{array}{l}\text { Imetelstat Sodium } \\
\text { (GRN163L) }\end{array}$ & 20 & $\begin{array}{l}\text { November } 2007 \text { to } \\
\text { July } 2011\end{array}$ & $\begin{array}{l}\text { DLT: } \\
\text { thrombocytopenia, } \\
\text { neutropenia, } \\
\text { anemia, aPTT } \\
\text { prolongation, } \\
\text { fatigue, nausea, } \\
\text { anorexia and } \\
\text { dizziness. }\end{array}$ \\
\hline $\begin{array}{l}\text { 11. NCT01243073 } \\
\text { Phase: II }\end{array}$ & $\begin{array}{l}\text { Essential } \\
\text { thrombocythemia }\end{array}$ & Safety and efficacy & $\begin{array}{l}\text { Imetelstat Sodium } \\
\text { (GRN163L }\end{array}$ & 20 & $\begin{array}{l}\text { December 2010- } \\
\text { April } 2015\end{array}$ & $\begin{array}{l}\text { Eighteen patients, } \\
\text { all with positive } \\
\text { hematologic } \\
\text { response. Positive } \\
\text { molecular response } \\
\text { in most patients } \\
\text { with } J A K 2 \text { V617F } \\
\text { mutation. ADRs: } \\
\text { neutropenia, } \\
\text { anemia. }\end{array}$ \\
\hline $\begin{array}{l}\text { 12. NCT00124189 } \\
\text { Phase: I }\end{array}$ & $\begin{array}{l}\text { Refractory chronic } \\
\text { lymphoproliferative } \\
\text { disease }\end{array}$ & $\begin{array}{l}\text { Safety, tolerability, } \\
\text { dose-limiting } \\
\text { toxicities, and MTD }\end{array}$ & $\begin{array}{l}\text { Imetelstat Sodium } \\
\text { (GRN163L }\end{array}$ & 48 & $\begin{array}{l}\text { July } 2005 \text { to March } \\
2013\end{array}$ & $\begin{array}{l}\text { No result has been } \\
\text { posted. }\end{array}$ \\
\hline
\end{tabular}

Table 3: The completed clinical trials of Imetelstat (GRN163L) according to ClinicalTrials.gov

Table 3: The completed cinical trials of Imetelstat (GRN163L) according to Clinical Trials.gov

要
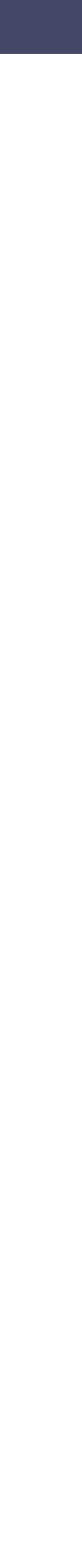
On the contrary, anti-telomerase immune-therapeutics has demonstrated positive outcomes in cancer treatment. Anti-telomerase immunotherapy's objective is to sensitize the immune system to tumor cells expressing hTERT peptides in order to activate and create hTERT specific CD8+ cells with improved anti-tumor effects. To create effective telomerase-based immunotherapy in cancer, two main methods have been used: a hTERT vaccination strategy and a dendritic cell approach to prepare antigen-presenting cells ex vivo. GV1001, Vx001, and GRNVAC1 are three hTERT vaccines that have been utilized to induce anti-telomerase immune responses in cancer patients [71]. GRNVAC1, Vx001, and GV1001 are promising telomerase-targeting vaccines that stimulate CD4+ and CD8+ responses in telomerase-positive tumors while having minimal effects on normal cells and no autoimmunity, according to clinical trial results (Figure 4). To determine long-term toxicities in patients, large multicenter studies are required. However, it is currently unknown whether any of these vaccine candidates will proceed to registration studies in order to gain approval for clinical use. The registered clinical trials on www.clinicaltrials.gov are listed in table 4: 


\begin{tabular}{|c|c|c|c|c|c|}
\hline $\begin{array}{l}\text { Vaccine Names \& } \\
\text { Identifier No }\end{array}$ & Functions & $\begin{array}{l}\text { Applied on } \\
\text { Cancer Type }\end{array}$ & Goal of the experiment & Start and End Date & Results \\
\hline $\begin{array}{c}\text { GRNVAC1 NCT00510133 } \\
\text { Phase: I }\end{array}$ & $\begin{array}{l}\text { GRNVAC1 is made up of mature autologous } \\
\text { dendritic cells that have been transduced with } \\
\text { hTERT and LAMP1 mRNA. } \\
\text { LAMP1 transports hTERT to the lysosomes, } \\
\text { where it is degraded into small peptides, trigg } \\
\text { ering a polyclonal immune response against al } \\
1 \text { hTERT epitopes expressed by patient tumors } \\
\text { [77]. After three or six weekly injections, GR } \\
\text { NVAC1 was found to be well tolerated with n } \\
\text { o signs of autoimmunity and elicited a robust } \\
\text { immune response in patients [78]. }\end{array}$ & $\begin{array}{c}\text { Acute } \\
\text { Myelogenous } \\
\text { Leukemia (AML) }\end{array}$ & $\begin{array}{c}\text { To determine the efficacy } \\
\text { of the trial. }\end{array}$ & $\begin{array}{l}\text { July 2007-August } \\
2014\end{array}$ & $\begin{array}{l}\text { It was observed to be safe } \\
\text { and well tolerated. } \\
\text { Positive immune responses in } \\
55 \% \text { of patients. } \\
\text { Toxicity: thrombocytopenia. }\end{array}$ \\
\hline $\begin{array}{l}\text { GV1001 } \\
\text { NCT01579188 } \\
\text { Phase: III }\end{array}$ & $\begin{array}{l}\text { Endogenous processing of the vaccine yields } \\
\text { an HLA class I peptide that elicits both CD4+ } \\
\text { and CD8+ responses, resulting in significant } \\
\text { cytotoxic T-lymphocyte activation [74]. }\end{array}$ & $\begin{array}{l}\text { Non-small-cell } \\
\text { lung cancer }\end{array}$ & $\begin{array}{c}\text { To determine the efficacy } \\
\text { of the trial. }\end{array}$ & $\begin{array}{l}\text { May } 2012- \\
\text { May } 2016\end{array}$ & No result has been posted \\
\hline $\begin{array}{l}\text { GV1001 } \\
\text { NCT00425360 } \\
\text { phase III }\end{array}$ & $\begin{array}{l}\text { Endogenous processing of the vaccine yields } \\
\text { an HLA class I peptide that elicits both CD4+ } \\
\text { and CD8+ responses, resulting in significant } \\
\text { cytotoxic T-lymphocyte activation [74]. }\end{array}$ & $\begin{array}{c}\text { Metastatic } \\
\text { pancreatic cancer }\end{array}$ & $\begin{array}{l}\text { To determine efficacy in } \\
\text { combination with } \\
\text { chemotherapy }\end{array}$ & $\begin{array}{l}\text { September 2006- } \\
\text { March } 2013\end{array}$ & $\begin{array}{l}\text { The addition of the GV1001 } \\
\text { vaccine to chemotherapy had } \\
\text { no effect on overall survival. }\end{array}$ \\
\hline $\begin{array}{c}\text { Vx001 } \\
\text { NCT01935154 } \\
\text { Phase: II }\end{array}$ & $\begin{array}{l}\text { The vaccine has a strong affinity for HLA cla } \\
\text { ss I and has shown a high rate of immune resp } \\
\text { onse in cancer patients }[75,76] \text {. }\end{array}$ & $\begin{array}{l}\text { Non-small-cell } \\
\text { lung cancer }\end{array}$ & $\begin{array}{l}\text { To determine the efficacy } \\
\text { of the trial. }\end{array}$ & $\begin{array}{l}\text { August 2012- } \\
\text { December } 2016\end{array}$ & No result has been posted \\
\hline
\end{tabular}

Table 4: Clinical Trials for Anti-Telomerase Vaccines. 


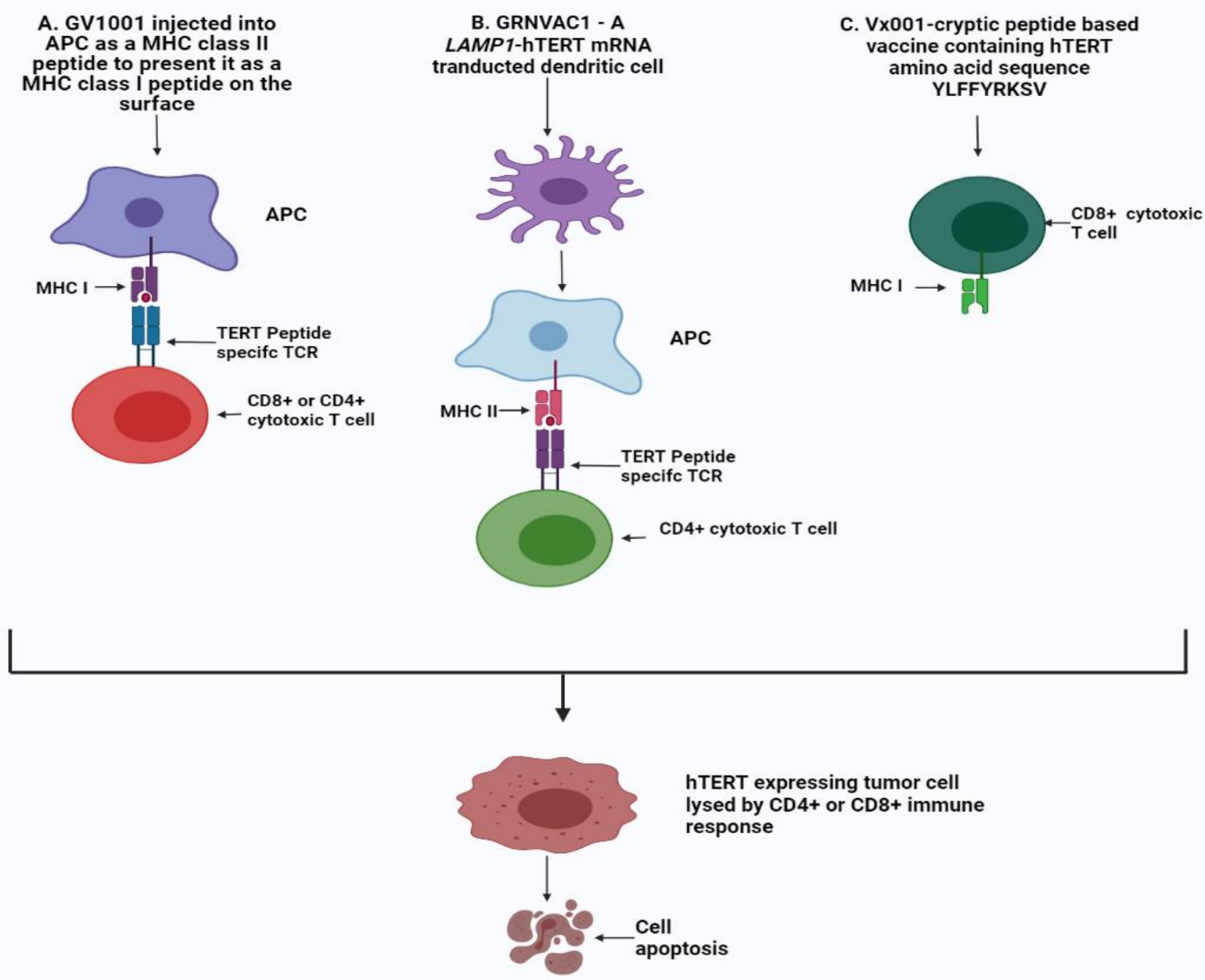

Figure 4: An overview of Anti-Telomerase immune-therapeutic vaccines producing CD8+ to induce death in tumor cell.

\section{Conclusion.}

Telomere attrition can cause numerous of age-related diseases along cancer. To ease this problem, transfer of genes to maintain telomere stability can be consider as a potential way to treat the agerelated diseases. The first human trial of telomerase gene transfer was reported in 2015 as a selfexperiment. Although the research did not get published to a peer reviewed journal, the company is gathering experimental data from researchers to support their statements to combat the age-related diseases. To develop new drugs to treat a specific disease, it takes a huge amount of time and cost. Multiple approaches have been taken to develop accurate drug for the treatment of cancer. [72]. Telomerase mediated gene therapy has the potential to lead cancer toward remission.

Throughout most instances, cancer is a genetic illness that develops over time as a result of the buildup of genomic instability. Cancer cells typically develop ways to avoid natural senescence caused by telomere attrition and attain immortality. Reactivation of TERT, which is increased in $85 \%$ of clinical cases, is the most often used method for telomere maintenance by cancer cells.

TERT reactivation is common in cancer patients, and it plays an important role in cancer longevity, making it an appealing therapeutic target for cancer treatment. 
Silencing or inhibition of TERT or TERC activity are further applications within the realm of gene therapy that exploit constitutive activation of TERT in cancer [73-75].For example, siRNA or antisense RNA targeting TERT has been a popular gene therapy [76-81], with a small number of studies examining various strategies (such as expression of the c-terminal TERT polypeptide (hTERTC27) [61,82,83], CRISPR/Cas9 targeting an oncogenic TERT promoter mutant allele that allows constitutive activation in cancer [84], or microRNA-mediated downregulation of TERT by targeting the 30 -UTR. These methods, in general, promote cellular senescence, cause apoptotic tumor cell death, and slow tumor growth.

Among all these approaches, AAVs mediated telomerase gene therapy has the most potential to be successful in human trials as numerous studies has shown that it has the significance to reduce cancer cells without effecting normal cells. 


\section{References}

1. Sahin, E., \& DePinho, R. A. (2010). Linking functional decline of telomeres, mitochondria and stem cells during ageing. nature, 464(7288), 520-528.

2. Moyzis, R. K., Buckingham, J. M., Cram, L. S., Dani, M., Deaven, L. L., Jones, M. D., ... \& Wu, J. R. (1988). A highly conserved repetitive DNA sequence, (TTAGGG) n, present at the telomeres of human chromosomes. Proceedings of the National Academy of Sciences, 85(18), 6622-6626.

3. Jafri, M. A., Ansari, S. A., Alqahtani, M. H., \& Shay, J. W. (2016). Roles of telomeres and telomerase in cancer, and advances in telomerase-targeted therapies. Genome medicine, 8(1), $1-18$.

4. Williams, T. L., Levy, D. L., Maki-Yonekura, S., Yonekura, K., \& Blackburn, E. H. (2010). Characterization of the yeast telomere nucleoprotein core: Rap1 binds independently to each recognition site. Journal of Biological Chemistry, 285(46), 35814-35824.

5. Martínez, P., \& Blasco, M. A. (2010). Role of shelterin in cancer and aging. Aging cell, 9(5), 653-666. https://doi.org/10.1111/j.1474-9726.2010.00596.x

6. Aschacher, T., Wolf, B., Enzmann, F., Kienzl, P., Messner, B., Sampl, S., Svoboda, M., Mechtcheriakova, D., Holzmann, K., \& Bergmann, M. (2016). LINE-1 induces hTERT and ensures telomere maintenance in tumour cell lines. Oncogene, 35(1), 94-104. https://doi.org/10.1038/onc.2015.65

7. Deng, Y., \& Chang, S. (2007). Role of telomeres and telomerase in genomic instability, senescence and cancer. Laboratory investigation; a journal of technical methods and pathology, 87(11), 1071-1076. https://doi.org/10.1038/labinvest.3700673

8. Shcherbakova, D. M., Zvereva, M. E., Shpanchenko, O. V., \& Dontsova, O. A. (2006). Molekuliarnaia biologiia, 40(4), 580-594.

9. Osterhage, J. L., Talley, J. M., \& Friedman, K. L. (2006). Proteasome-dependent degradation of Est $1 p$ regulates the cell cycle-restricted assembly of telomerase in Saccharomyces cerevisiae. Nature structural \& molecular biology, 13(8), 720-728. https://doi.org/10.1038/nsmb1125

10. Hsu, M., Yu, E. Y., Singh, S. M., \& Lue, N. F. (2007). Mutual dependence of Candida albicans Est1p and Est3p in telomerase assembly and activation. Eukaryotic cell, 6(8), 13301338. https://doi.org/10.1128/EC.00069-07

11. Collins K. (2006). The biogenesis and regulation of telomerase holoenzymes. Nature reviews. Molecular cell biology, 7(7), 484-494. https://doi.org/10.1038/nrm1961

12. Mozdy, A. D., Podell, E. R., \& Cech, T. R. (2008). Multiple yeast genes, including Paf1 complex genes, affect telomere length via telomerase RNA abundance. Molecular and cellular biology, 28(12), 4152-4161. https://doi.org/10.1128/MCB.00512-08

13. Cristofari, G., \& Lingner, J. (2006). Telomere length homeostasis requires that telomerase levels are limiting. The EMBO journal, 25(3), 565-574.

https://doi.org/10.1038/sj.emboj.7600952

14. Denchi E. L. (2009). Give me a break: how telomeres suppress the DNA damage response. DNA repair, 8(9), 1118-1126. https://doi.org/10.1016/j.dnarep.2009.04.013

15. Shay J. W. (2013). Are short telomeres predictive of advanced cancer? Cancer discovery, 3(10), 1096-1098. https://doi.org/10.1158/2159-8290.CD-13-0506

16. Horn, S., Figl, A., Rachakonda, P. S., Fischer, C., Sucker, A., Gast, A., Kadel, S., Moll, I., Nagore, E., Hemminki, K., Schadendorf, D., \& Kumar, R. (2013). TERT promoter mutations in familial and sporadic melanoma. Science (New York, N.Y.), 339(6122), 959-961. https://doi.org/10.1126/science.1230062

17. Huang, F. W., Hodis, E., Xu, M. J., Kryukov, G. V., Chin, L., \& Garraway, L. A. (2013). Highly recurrent TERT promoter mutations in human melanoma. Science (New York, N.Y.), 339(6122), 957-959. https://doi.org/10.1126/science.1229259 
18. Vinagre, J., Almeida, A., Pópulo, H., Batista, R., Lyra, J., Pinto, V., Coelho, R., Celestino, R., Prazeres, H., Lima, L., Melo, M., da Rocha, A. G., Preto, A., Castro, P., Castro, L., Pardal, F., Lopes, J. M., Santos, L. L., Reis, R. M., Cameselle-Teijeiro, J., ... Soares, P. (2013).

Frequency of TERT promoter mutations in human cancers. Nature communications, 4, 2185. https://doi.org/10.1038/ncomms3185

19. Killela, P. J., Reitman, Z. J., Jiao, Y., Bettegowda, C., Agrawal, N., Diaz, L. A., Jr, Friedman, A. H., Friedman, H., Gallia, G. L., Giovanella, B. C., Grollman, A. P., He, T. C., He, Y., Hruban, R. H., Jallo, G. I., Mandahl, N., Meeker, A. K., Mertens, F., Netto, G. J., Rasheed, B. A., ... Yan, H. (2013). TERT promoter mutations occur frequently in gliomas and a subset of tumors derived from cells with low rates of self-renewal. Proceedings of the National Academy of Sciences of the United States of America, 110(15), 6021-6026. https://doi.org/10.1073/pnas.1303607110

20. Borah, S., Xi, L., Zaug, A. J., Powell, N. M., Dancik, G. M., Cohen, S. B., Costello, J. C., Theodorescu, D., \& Cech, T. R. (2015). Cancer. TERT promoter mutations and telomerase reactivation in urothelial cancer. Science (New York, N.Y.), 347(6225), 1006-1010. https://doi.org/10.1126/science. 1260200

21. Schmidt, J. C., \& Cech, T. R. (2015). Human telomerase: biogenesis, trafficking, recruitment, and activation. Genes \& development, 29(11), 1095-1105.

https://doi.org/10.1101/gad.263863.115

22. Hsu, C. P., Lee, L. W., Tang, S. C., Hsin, I. L., Lin, Y. W., \& Ko, J. L. (2015). Epidermal growth factor activates telomerase activity by direct binding of Ets- 2 to hTERT promoter in lung cancer cells. Tumour biology: the journal of the International Society for Oncodevelopmental Biology and Medicine, 36(7), 5389-5398. https://doi.org/10.1007/s13277-015-3204-x23

23. Chan, A. K., Yao, Y., Zhang, Z., Chung, N. Y., Liu, J. S., Li, K. K., Shi, Z., Chan, D. T., Poon, W. S., Zhou, L., \& Ng, H. K. (2015). TERT promoter mutations contribute to subset prognostication of lower-grade gliomas. Modern pathology: an official journal of the United States and Canadian Academy of Pathology, Inc, 28(2), 177-186. https://doi.org/10.1038/modpathol.2014.94

24. Gavas, S.; Quazi, S.; Karpiński, T. Nanoparticles for Cancer Therapy: Current Progress and Challenges. Preprints 2021, 2021080218 https://doi.org10.20944/preprints202108.0218.v1

25. Huang, F. W., Bielski, C. M., Rinne, M. L., Hahn, W. C., Sellers, W. R., Stegmeier, F., Garraway, L. A., \& Kryukov, G. V. (2015). TERT promoter mutations and monoallelic activation of TERT in cancer. Oncogenesis, 4(12), e176. https://doi.org/10.1038/oncsis.2015.39

26. Heidenreich, B., Rachakonda, P. S., Hemminki, K., \& Kumar, R. (2014). TERT promoter mutations in cancer development. Current opinion in genetics \& development, 24, 30-37. https://doi.org/10.1016/j.gde.2013.11.005

27. Liu, T., Yuan, X., \& Xu, D. (2016). Cancer-Specific Telomerase Reverse Transcriptase (TERT) Promoter Mutations: Biological and Clinical Implications. Genes, 7(7), 38. https://doi.org/10.3390/genes7070038

28. Barthel, F. P., Wei, W., Tang, M., Martinez-Ledesma, E., Hu, X., Amin, S. B., Akdemir, K. C., Seth, S., Song, X., Wang, Q., Lichtenberg, T., Hu, J., Zhang, J., Zheng, S., \& Verhaak, R. G. (2017). Systematic analysis of telomere length and somatic alterations in 31 cancer types. Nature genetics, 49(3), 349-357.

29. Chiba, K., Johnson, J. Z., Vogan, J. M., Wagner, T., Boyle, J. M., \& Hockemeyer, D. (2015). Cancer-associated TERT promoter mutations abrogate telomerase silencing. eLife, 4, e07918. https://doi.org/10.7554/eLife.07918

30. Li, C., Wu, S., Wang, H., Bi, X., Yang, Z., Du, Y., He, L., Cai, Z., Wang, J., \& Fan, Z. (2015). The C228T mutation of TERT promoter frequently occurs in bladder cancer stem 
cells and contributes to tumorigenesis of bladder cancer. Oncotarget, 6(23), 19542-19551. https://doi.org/10.18632/oncotarget.4295

31. Bell, R. J., Rube, H. T., Kreig, A., Mancini, A., Fouse, S. D., Nagarajan, R. P., Choi, S., Hong, C., He, D., Pekmezci, M., Wiencke, J. K., Wrensch, M. R., Chang, S. M., Walsh, K. M., Myong, S., Song, J. S., \& Costello, J. F. (2015). Cancer. The transcription factor GABP selectively binds and activates the mutant TERT promoter in cancer. Science (New York, N.Y.), 348(6238), 1036-1039. https://doi.org/10.1126/science.aab0015

32. Mancini, A., Xavier-Magalhães, A., Woods, W. S., Nguyen, K. T., Amen, A. M., Hayes, J. L., Fellmann, C., Gapinske, M., McKinney, A. M., Hong, C., Jones, L. E., Walsh, K. M., Bell, R., Doudna, J. A., Costa, B. M., Song, J. S., Perez-Pinera, P., \& Costello, J. F. (2018). Disruption of the $\beta 1 \mathrm{~L}$ Isoform of GABP Reverses Glioblastoma Replicative Immortality in a TERT Promoter Mutation-Dependent Manner. Cancer cell, 34(3), 513-528.e8. https://doi.org/10.1016/j.ccell.2018.08.003

33. Stern, J. L., Theodorescu, D., Vogelstein, B., Papadopoulos, N., \& Cech, T. R. (2015). Mutation of the TERT promoter, switch to active chromatin, and monoallelic TERT expression in multiple cancers. Genes \& development, 29(21), 2219-2224. https://doi.org/10.1101/gad.269498.115

34. Sizemore, G. M., Pitarresi, J. R., Balakrishnan, S., \& Ostrowski, M. C. (2017). The ETS family of oncogenic transcription factors in solid tumours. Nature reviews. Cancer, 17(6), 337-351. https://doi.org/10.1038/nrc.2017.20

35. Yuan, X., Mu, N., Wang, N., Strååt, K., Sofiadis, A., Guo, Y., Stenman, A., Li, K., Cheng, G., Zhang, L., Kong, F., Ekblad, L., Wennerberg, J., Nilsson, I. L., Juhlin, C. C., Larsson, C., \& Xu, D. (2019). GABPA inhibits invasion/metastasis in papillary thyroid carcinoma by regulating DICER1 expression. Oncogene, 38(7), 965-979. https://doi.org/10.1038/s41388018-0483-X

36. Xie, H., Liu, T., Wang, N., Björnhagen, V., Höög, A., Larsson, C., Lui, W. O., \& Xu, D. (2014). TERT promoter mutations and gene amplification: promoting TERT expression in Merkel cell carcinoma. Oncotarget, 5(20), 10048-10057. https://doi.org/10.18632/oncotarget.2491

37. Mitchell, T. J., Turajlic, S., Rowan, A., Nicol, D., Farmery, J., O'Brien, T., Martincorena, I., Tarpey, P., Angelopoulos, N., Yates, L. R., Butler, A. P., Raine, K., Stewart, G. D., Challacombe, B., Fernando, A., Lopez, J. I., Hazell, S., Chandra, A., Chowdhury, S., Rudman, S., ... TRACERx Renal Consortium (2018). Timing the Landmark Events in the Evolution of Clear Cell Renal Cell Cancer: TRACERx Renal. Cell, 173(3), 611-623.e17. https://doi.org/10.1016/j.cell.2018.02.020

38. Liu, T., Wang, N., Cao, J., Sofiadis, A., Dinets, A., Zedenius, J., Larsson, C., \& Xu, D. (2014). The age- and shorter telomere-dependent TERT promoter mutation in follicular thyroid cell-derived carcinomas. Oncogene, 33(42), 4978-4984. https://doi.org/10.1038/onc.2013.446

39. Chiba, K., Lorbeer, F. K., Shain, A. H., McSwiggen, D. T., Schruf, E., Oh, A., Ryu, J., Darzacq, X., Bastian, B. C., \& Hockemeyer, D. (2017). Mutations in the promoter of the telomerase gene TERT contribute to tumorigenesis by a two-step mechanism. Science (New York, N.Y.), 357(6358), 1416-1420. https://doi.org/10.1126/science.aao0535

40. Maryoung, L., Yue, Y., Young, A., Newton, C. A., Barba, C., van Oers, N. S., Wang, R. C., \& Garcia, C. K. (2017). Somatic mutations in telomerase promoter counterbalance germline loss-of-function mutations. The Journal of clinical investigation, 127(3), 982-986. https://doi.org/10.1172/JCI91161

41. Yuan, X., Cheng, G., Yu, J., Zheng, S., Sun, C., Sun, Q., Li, K., Lin, Z., Liu, T., Li, P., Xu, Y., Kong, F., Bjorkholm, M., \& Xu, D. (2017). The TERT promoter mutation incidence is modified by germline TERT rs2736098 and rs2736100 polymorphisms in hepatocellular carcinoma. Oncotarget, 8(14), 23120-23129. https://doi.org/10.18632/oncotarget.15498 
42. Dahlström, J., Liu, T., Yuan, X., Saft, L., Ghaderi, M., Wei, Y. B., Lavebratt, C., Li, P., Zheng, C., Björkholm, M., \& Xu, D. (2016). TERT rs2736100 genotypes are associated with differential risk of myeloproliferative neoplasms in Swedish and Chinese male patient populations. Annals of hematology, 95(11), 1825-1832. https://doi.org/10.1007/s00277-0162787-7

43. Hanahan, D., \& Weinberg, R. A. (2011). Hallmarks of cancer: the next generation. Cell, 144(5), 646-674. https://doi.org/10.1016/j.cell.2011.02.013

44. Liu, C., Fang, X., Ge, Z., Jalink, M., Kyo, S., Björkholm, M., Gruber, A., Sjöberg, J., \& Xu, D. (2007). The telomerase reverse transcriptase (hTERT) gene is a direct target of the histone methyltransferase SMYD3. Cancer research, 67(6), 2626-2631. https://doi.org/10.1158/00085472.CAN-06-4126

45. Strååt, K., Liu, C., Rahbar, A., Zhu, Q., Liu, L., Wolmer-Solberg, N., Lou, F., Liu, Z., Shen, J., Jia, J., Kyo, S., Björkholm, M., Sjöberg, J., Söderberg-Nauclér, C., \& Xu, D. (2009).

Activation of telomerase by human cytomegalovirus. Journal of the National Cancer Institute, 101(7), 488-497. https://doi.org/10.1093/jnci/djp031

46. Bell, R. J., Rube, H. T., Xavier-Magalhães, A., Costa, B. M., Mancini, A., Song, J. S., \& Costello, J. F. (2016). Understanding TERT Promoter Mutations: A Common Path to Immortality. Molecular cancer research: MCR, 14(4), 315-323. https://doi.org/10.1158/15417786.MCR-16-0003

47. Barthel, F. P., Wei, W., Tang, M., Martinez-Ledesma, E., Hu, X., Amin, S. B., Akdemir, K. C., Seth, S., Song, X., Wang, Q., Lichtenberg, T., Hu, J., Zhang, J., Zheng, S., \& Verhaak, R. G. (2017). Systematic analysis of telomere length and somatic alterations in 31 cancer types. Nature genetics, 49(3), 349-357. https://doi.org/10.1038/ng.3781

48. Quazi, S. Role of Artificial Intelligence and Machine Learning in Bioinformatics: Drug Discovery and Drug Repurposing. Preprints 2021, 2021050346 https://doi.org/10.20944/preprints202105.0346.v1

49. Buseman, C. M., Wright, W. E., \& Shay, J. W. (2012). Is telomerase a viable target in cancer? Mutation research, 730(1-2), 90-97. https://doi.org/10.1016/j.mrfmmm.2011.07.006

50. Dai, W., Xu, X., Wang, D., Wu, J., \& Wang, J. (2019). Cancer therapy with a CRISPRassisted telomerase-activating gene expression system. Oncogene, 38(21), 4110-4124. https://doi.org/10.1038/s41388-019-0707-8

51. Keith, N., Bilsland, A. E., Anderson, C. J., Monaghan, A. J., \& Plumb, J. A. (2003). 336. Telomerase-Directed Suicide Gene Therapy: An Analysis of hTR and hTERT Promoters. Molecular Therapy, 7(5).

52. Quazi, S. Elucidation of CRISPR-Cas9 Application in Novel Cellular Immunotherapy. Preprints 2021, 2021080387 https://doi.org10.20944/preprints202108.0387.v1

53. Quazi, S. An Overview of CAR T Cell Mediated B Cell Maturation Antigen Therapy. Preprints 2021, 2021090212 https://doi.org/10.20944/preprints202109.0212.v1

54. Quazi, S. Artificial Intelligence and Machine Learning in Precision and Genomic Medicine. Preprints 2021, 2021100011 https://doi.org/10.20944/preprints202110.0011

55. Huang, X., Zhuang, C., Zhuang, C., Xiong, T., Li, Y., \& Gui, Y. (2017). An enhanced hTERT promoter driven CRISPR/Cas9 system selectively inhibits the progression of bladder cancer cells. Molecular bioSystems, 13(9), 1713-1721. https://doi.org/10.1039/c7mb00354d

56. Kim, E., Kim, J. H., Shin, H. Y., Lee, H., Yang, J. M., Kim, J., Sohn, J. H., Kim, H., \& Yun, C. O. (2003). Ad-mTERT-delta19, a conditional replication-competent adenovirus driven by the human telomerase promoter, selectively replicates in and elicits cytopathic effect in a cancer cell-specific manner. Human gene therapy, 14(15), 1415-1428. https://doi.org/10.1089/104303403769211637

57. Li, Y., Hong, J., Oh, J. E., Yoon, A. R., \& Yun, C. O. (2018). Potent antitumor effect of tumor microenvironment-targeted oncolytic adenovirus against desmoplastic pancreatic cancer. International journal of cancer, 142(2), 392-413. https://doi.org/10.1002/ijc.31060 
58. Oh, E., Hong, J., Kwon, O. J., \& Yun, C. O. (2018). A hypoxia- and telomerase-responsive oncolytic adenovirus expressing secretable trimeric TRAIL triggers tumour-specific apoptosis and promotes viral dispersion in TRAIL-resistant glioblastoma. Scientific reports, 8(1), 1420. https://doi.org/10.1038/s41598-018-19300-6

59. Huang, J. J., Lin, M. C., Bai, Y. X., Jing, D. D., Wong, B. C., Han, S. W., Lin, J., Xu, B., Huang, C. F., \& Kung, H. F. (2002). Ectopic expression of a COOH-terminal fragment of the human telomerase reverse transcriptase leads to telomere dysfunction and reduction of growth and tumorigenicity in HeLa cells. Cancer research, 62(11), 3226-3232.

60. Huang, J., Bai, Y. X., Han, S. W., Ng, S. S., Wong, B. C., Huang, C. F., ... \& Lin, M. C. (2003). A human TERT C-terminal polypeptide sensitizes HeLa cells to H2O2-induced senescence without affecting telomerase enzymatic activity. Biochemical and biophysical research communications, 301(3), 627-632.

61. Bryan, T. M., Englezou, A., Gupta, J., Bacchetti, S., \& Reddel, R. R. (1995). Telomere elongation in immortal human cells without detectable telomerase activity. The EMBO journal, 14(17), 4240-4248.

62. Cesare, A. J., \& Reddel, R. R. (2010). Alternative lengthening of telomeres: models, mechanisms and implications. Nature reviews. Genetics, 11(5), 319-330. https://doi.org/10.1038/nrg2763

63. Ng, S. S., Gao, Y., Chau, D. H., Li, G. H., Lai, L. H., Huang, P. T., Huang, C. F., Huang, J. J., Chen, Y. C., Kung, H. F., \& Lin, M. C. (2007). A novel glioblastoma cancer gene therapy using AAV-mediated long-term expression of human TERT C-terminal polypeptide. Cancer gene therapy, 14(6), 561-572. https://doi.org/10.1038/sj.cgt.7701038

64. Quazi S. Vaccine in response to COVID-19: Recent developments, challenges, and a way out. Biomed Biotechnol Res J 2021;5: 105-9 https://doi.org/10.4103/bbrj.bbrj_166_20

65. Jackson, S. R., Zhu, C. H., Paulson, V., Watkins, L., Dikmen, Z. G., Gryaznov, S. M., Wright, W. E., \& Shay, J. W. (2007). Antiadhesive effects of GRN163L--an oligonucleotide N3'->P5' thio-phosphoramidate targeting telomerase. Cancer research, 67(3), 1121-1129. https://doi.org/10.1158/0008-5472.CAN-06-2306

66. Herbert, B. S., Gellert, G. C., Hochreiter, A., Pongracz, K., Wright, W. E., Zielinska, D., Chin, A. C., Harley, C. B., Shay, J. W., \& Gryaznov, S. M. (2005). Lipid modification of GRN163, an N3'-->P5' thio-phosphoramidate oligonucleotide, enhances the potency of telomerase inhibition. Oncogene, 24(33), 5262-5268. https://doi.org/10.1038/sj.onc.1208760

67. Marian, C. O., Wright, W. E., \& Shay, J. W. (2010). The effects of telomerase inhibition on prostate tumor-initiating cells. International journal of cancer, 127(2), 321-331. https://doi.org/10.1002/ijc.25043

68. Burchett, K. M., Yan, Y., \& Ouellette, M. M. (2014). Telomerase inhibitor Imetelstat (GRN163L) limits the lifespan of human pancreatic cancer cells. PloS one, 9(1), e85155. https://doi.org/10.1371/journal.pone.0085155

69. Hu, Y., Bobb, D., He, J., Hill, D. A., \& Dome, J. S. (2015). The HSP90 inhibitor alvespimycin enhances the potency of telomerase inhibition by imetelstat in human osteosarcoma. Cancer biology \& therapy, 16(6), 949-957.

https://doi.org/10.1080/15384047.2015.1040964

70. Dikmen, Z. G., Gellert, G. C., Jackson, S., Gryaznov, S., Tressler, R., Dogan, P., Wright, W. E., \& Shay, J. W. (2005). In vivo inhibition of lung cancer by GRN163L: a novel human telomerase inhibitor. Cancer research, 65(17), 7866-7873. https://doi.org/10.1158/00085472.CAN-05-1215

71. Marian, C. O., Cho, S. K., McEllin, B. M., Maher, E. A., Hatanpaa, K. J., Madden, C. J., Mickey, B. E., Wright, W. E., Shay, J. W., \& Bachoo, R. M. (2010). The telomerase antagonist, imetelstat, efficiently targets glioblastoma tumor-initiating cells leading to decreased proliferation and tumor growth. Clinical cancer research: an official journal of the 
American Association for Cancer Research, 16(1), 154-163. https://doi.org/10.1158/10780432.CCR-09-2850

72. Lu, R., Pal, J., Buon, L., Nanjappa, P., Shi, J., Fulciniti, M., Tai, Y. T., Guo, L., Yu, M., Gryaznov, S., Munshi, N. C., \& Shammas, M. A. (2014). Targeting homologous recombination and telomerase in Barrett's adenocarcinoma: impact on telomere maintenance, genomic instability and tumor growth. Oncogene, 33(12), 1495-1505. https://doi.org/10.1038/onc.2013.103

73. Ruden, M., \& Puri, N. (2013). Novel anticancer therapeutics targeting telomerase. Cancer treatment reviews, 39(5), 444-456. https://doi.org/10.1016/j.ctrv.2012.06.007\}

74. Quazi, S.; Jangi, R. Artificial Intelligence and Machine Learning in Medicinal Chemistry and Validation of Emerging Drug Targets. Preprints 2021, 2021050567 https://doi.org/10.20944/preprints202105.0567.v1

75. Chen, M., \& Xing, L. N. (2012). siRNA-mediated inhibition of hTERC enhances radiosensitivity of cervical cancer. Asian Pacific Journal of Cancer Prevention, 13(12), 59755979.

76. Li, Y., Li, M., Yao, G., Geng, N., Xie, Y., Feng, Y., Zhang, P., Kong, X., Xue, J., Cheng, S., Zhou, J., \& Xiao, L. (2011). Telomerase inhibition strategies by siRNAs against either hTR or hTERT in oral squamous cell carcinoma. Cancer gene therapy, 18(5), 318-325. https://doi.org/10.1038/cgt.2010.81

77. Cheng, W., Wei, Z., Gao, J., Zhang, Z., Ge, J., Jing, K., Xu, F., \& Xie, P. (2010). Effects of combined siRNA-TR and -TERT on telomerase activity and growth of bladder transitional cell cancer BIU-87 cells. Journal of Huazhong University of Science and Technology [Medical Sciences], 30(3), 391-396. https://doi.org/10.1007/s11596-010-0363-2

78. Deng, Z. (2011). Effect of plasmid-mediated RNA interference targeting telomerase reverse transcriptase on lung cancer cells. Oncology Reports. Published. https://doi.org/10.3892/or.2011.1455

79. Xia, W., \& Lin, C. (2012). Bioreducible polymer-delivered siRNA targeting human telomerase reverse transcriptase for human cancer gene therapy. Therapeutic delivery, 3(4), 439-442. https://doi.org/10.4155/tde.12.24

80. Zhao, X., Zhang, C., Le, Z., Zeng, S., Pan, C., Shi, J., Wang, J., \& Zhao, X. (2018). Telomerase reverse transcriptase interference synergistically promotes tumor necrosis factor related apoptosis inducing ligand induced oral squamous cell carcinoma apoptosis and suppresses proliferation in-vitro and in-vivo. International Journal of Molecular Medicine. Published. https://doi.org/10.3892/ijmm.2018.3721

81. Sakiragaoglu, O., \& Munn, A. L. (2016). Inhibition of Telomerase Activity Using an EGFPIntron Splicing System Encoding Multiple RNAi Sequences. Molecular biotechnology, 58(12), 832-837. https://doi.org/10.1007/s12033-016-9982-6

82. ZHANG, W., \& XING, L. (2013). RNAi gene therapy of SiHa cells via targeting human TERT induces growth inhibition and enhances radiosensitivity. International Journal of Oncology, 43(4), 1228-1234. https://doi.org/10.3892/ijo.2013.2051

83. Kunze, D., Wuttig, D., Kausch, I., Blietz, C., Blumhoff, L., Burmeister, Y., ... \& Wirth, M. P. (2008). Antisense-mediated inhibition of survivin, hTERT and VEGF in bladder cancer cells in vitro and in vivo. International journal of oncology, 32(5), 1049-1056.

84. Yue, P. J., He, L., Li, Y., Shen, Q. Y., Li, M., Huang, D. Q., ... \& Peng, Y. (2013). Preclinical safety evaluation of rAd5-hTERTC27 by intravenous injection. Regulatory Toxicology and Pharmacology, 67(1), 53-62.

85. Gong, H. X., He, L., Li, X. P., Wang, Y. D., Li, Y., Huang, J. J., ... \& Peng, Y. (2012). Effective antitumor immunity against murine gliomas using dendritic cells transduced with hTERTC27 recombinant adenovirus. Oncology reports, 27(4), 1163-1169. 
86. Xi, L., Schmidt, J. C., Zaug, A. J., Ascarrunz, D. R., \& Cech, T. R. (2015). A novel two-step genome editing strategy with CRISPR-Cas9 provides new insights into telomerase action and TERT gene expression. Genome biology, 16(1), 1-17. 